GOSPODARKA SUROWCAMI MINERALNYMI - MINERAL RESOURCES MANAGEMENT

2016

Volume 32

Issue 4

Pages 5-28

DOI 10.1515/gospo-2016-0036

\title{
Rare earth elements pilot studies of the baltic marine sands enriched in heavy minerals
}

\section{Introduction}

The use of a number of elements that rarely formed economic deposits, but they are of major importance for the economy of the countries in the European Union is of key importance in modern industrial production. The rare earth elements (REE), which were considered critical for the economic development of the most developed countries of the EU are among these elements (Opinion 2006; Galos and Smakowski 2008; EU Resolution 2011; Moss et al. 2011; Smakowski 2011; Szamałek 2011; Galos et al. 2012). The most important among the latest REE technologies are: lanthanum, europium, erbium and neodymium (Chakhmouradian and Wall 2012; Haque et al. 2014; Paulo and Krzak 2015).

In recent years, the global production of rare earths oxides (REO) has been at the level of the 123-124 thousand tons/year (Smakowski et al. 2012; USGS minerals, 2016). The rare earth metals market is controlled by China, which has the world's largest resources (> 20\%; approx. 55 million tons) and annually provides more than 95 percent of the demand for rare earth materials (Hatch 2012). Chinese restrictions in the export of REE over the past few years have led to international concerns about future supply shortages

* Ph.D., D.Sc., Assoc. Prof., Polish Geological Institute-National Research Institute, Warszawa, Poland; e-mail: stanislaw.mikulski@pgi.gov.pl

** Ph.D., Polish Geological Institute-National Research Institute, Marine Geology Branch, Gdańsk-Oliwa, Poland; e-mail: regina.kramarska@pgi.gov.pl

*** Ph.D., Polish Geological Institute-National Research Institute, Warszawa, Poland; e-mail: grzegorz.zieliński@pgi.gov.pl 
(Klupa 2012). Despite this fact, the world REE resources are giant (about 130 million tons REO; USGS minerals, 2016) and sufficient to cover the current volume of demand for more than 1,000 years.

Minerals that contain REE occur in the form of primary and secondary concentrations in several genetic types of deposits (Paulo 1999). The most important among the primary deposits are those related to alkaline magmatic complexes and carbonatites (Mariano and Mariano 2012; Kynicky et al. 2012). The main ore minerals in these deposits are: bastnäsite $\left[\mathrm{La}, \mathrm{Ce}, \mathrm{Y}\left(\mathrm{CO}_{3}\right) \mathrm{F}\right]$, allanite $\left[(\mathrm{Ce}, \mathrm{Ca}, \mathrm{Y})_{2}(\mathrm{Al}, \mathrm{Fe}+++)_{3}\left(\mathrm{SiO}_{4}\right)_{3}(\mathrm{OH})\right]$, monazite $[(\mathrm{Ce}, \mathrm{La}, \mathrm{Nd}, \mathrm{Th})$ $\mathrm{PO}_{4}$, apatite $\left[\mathrm{Ca}_{5}\left(\mathrm{PO}_{4}\right)_{3}(\mathrm{OH}, \mathrm{F}, \mathrm{Cl})\right]$ and pyrochlore $\left[(\mathrm{Na}, \mathrm{Ca})_{2} \mathrm{Nb}_{2} \mathrm{O}_{6}(\mathrm{OH}, \mathrm{F})\right]$. The placer deposits, especially sands from the shoreline formation (Ti-Zr-REE-Th), in which the REE-bearing minerals are primarily, monazite, and xenotime [YPO4] that occur with zircon $\left[\mathrm{Zr}\left(\mathrm{SiO}_{4}\right)\right]$, ilmenite $\left[\mathrm{FeTiO}_{3}\right]$ and from the second formation represented by cassiterite sands $\left[\mathrm{SnO}_{2}\right](\mathrm{Sn}-\mathrm{Ta}-\mathrm{Nb}-\mathrm{Y})$ with xenotime (Long et al. 2010; Szamałek et al. 2013) are also important. In the first formation, the content of REE-bearing minerals (mainly monazite) ranges from 0.3 to $5 \%$ among heavy minerals (in India to 20\%; Paulo and Krzak 2015). In turn, the share of heavy fraction can be from 3 to $60 \%$ of quartz sands that form the mainly coastal bars. Monazite and xenotime are by-products of the enrichment of ilmenite-zircons sands. The production of this type heavy minerals concentrates is carried out mainly in Western Australia, Brazil and India (Collins and Baxter 1984; Hedrick 1997; Long et al. 2010; Paulo and Krzak 2015). In turn, the production of cassiterite concentrates (along with xenotime) on the largest scales takes place on the shelf in the south-eastern Asia (e.g. in Malaysia, Thailand and Indonesia; Economic 1988; Hedrick 1997; Szamałek et al. 2013).

In Poland, the perspective of REE deposit occurrence, despite the evidence of their resources in the two deposits in the Sudety Mountains (Kanasiewicz 1987), were judged very critically by some researchers (Paulo 1993). Recognized in NE Poland by deep drilling REE mineralization associated with carbonatites and alkaline magmatism is not of any economic importance to date (Kubicki 1987; Krzemińska and Krzemiński 2012, and references therein). Marine sands from the Polish coast and bottom of the Baltic Sea were also the subjects of works in the field of the concentration of REE in heavy minerals. These studies focused around three main issues: the composition of heavy minerals and conditions of placers formation (Zwierzycki 1947; Sawicka 1953; Łoziński and Masicka 1959; Mączka and Racinowski 1960; Wajda 1970, 1977; Kotliński 1985; Kramarska 1991) prognoses of resources (Kotliński and Kramarska 1977; Jurowska et al. 1978; Wajda 1980, 1982; Mapa geologiczna... 1989-1995; Kramarska 1993; Jones 1994; Kramarska et al. 2005) and the implementation issues relating to the technology of extraction, processing and the use of components especially in marine sands from the Odra Bank, Słupsk Bank and from the Łeba region (Akerman and Krajewski 1959; Juskowiak et al. 1976; Rosińska 1981; Łuszczkiewicz 1984; Łuszczkiewicz et al. 1988; Bagdach and Lasko 1989). Oder Geological documentation of heavy minerals and sands resources in D categories were made for the Odra Bank (ca. 13323.20 thousand tons, including 505.74 thousand tons of heavy minerals; Kaulbarsz et al. 2013). 
In this article we present the pilot REE results in several samples of marine sands collected from the Polish coast of the Baltic Sea and sandbanks of the southern Baltic that were made in PIG-PIB under the theme of Mikulski et al. (2014). Other data in terms of REE distribution in other geological areas in Poland are presented in separate articles (Mikulski et al. 2015; Brański and Mikulski 2016; Oszczepalski et al. 2016).

\section{Distribution and genesis of heavy minerals concentration in the Baltic marine sediments}

The Pleistocene deposits of glacial and fluvioglacial accumulation that were subject to different in time processes of abrasion and re-deposition are the direct source of heavy minerals in marine sediments in the Baltic Sea (Sawicka 1953; Łoziński and Masicka 1959; Kotliński 1985). Concentrations of certain minerals in the marine sands are of secondary nature. The source rocks for these minerals are crystalline and sedimentary rocks of Scandinavia and the bottom of the Baltic Sea. The accumulation of heavy minerals is associated with the selective implementation of the movement of mineral grains of a defined size and habit, under the influence of bottom currents and a complex mechanism of grain transportation (Leontjew et al. 1982; Haas et al. 1995; Dill 2007; Dill et al. 2012). Heavy minerals from the Baltic sands are represented by transparent components (quartz, garnet, amphibole, pyroxene, epidote, chlorite, and biotite) and opaque minerals (mainly ilmenite, and rarer by magnetite). Participation of other minerals (glauconite, staurolite, tourmaline, zircon, rutile, andalusite, sillimanite and apatite) and other mineral groups (e.g. carbonates) is subordinate (Sawicka 1953; Wajda 1970; Jurowska et al. 1978). The contents of heavy minerals (tested mainly in the $0.25-0.125 \mathrm{~mm}$ fraction) is mostly from 1 to $2 \%$. Concentrations above 3 weight $\%$ create an isolated field in the sands, in the shallow water of the sea within the range of the intense impact of wave and bottom currents, typically to a depth of the sea 10-30 m, and a little deeper on the thresholds separating deep-water basins (Mapa... 1989-1995; Kramarska et al. 2005).

The analysis of the distribution of concentration and granular grain composition of sediments indicates that perspective, in terms of exploration, are sediments associated with the relics of the bay-bar accumulation from the period of the Littorina Baltic Sea transgression in the Middle Holocene (Jurowska et al. 1978; Kramarska 1998). High concentrations of up to $20 \%$ occur in the sands of Odra Bank, a designated string shoals from the Eastern arm of this form to Kołobrzeg (Kramarska et al. 2005). Less well preserved relics of the spit, with the extremely high concentration of heavy minerals in the Polish zone of the Baltic Sea up to $45 \%$, occur in Central and Eastern parts of the Słupsk Bank (Kotliński and Kramarska 1977).

On the Slupsk Bank, the total area of the three fields with the concentration of heavy minerals is a dozen $\mathrm{km}^{2}$. The contents of fractions $0.063-0.25 \mathrm{~mm}$ in length is more than 
$90 \%$. Enrichment of heavy minerals in the laminas (2-10 mm thick) are correlated with the subsurface layer of the sands at about $30 \mathrm{~cm}$ of the thickness (Kotliński and Kramarska 1977).

On the Odra Bank, the documentation of resources only covers two placer fields (box A and box B, a total of approximately 1,303.49 ha) in the prospective areas (Kramarska et al. 2016). The contents of heavy minerals ranges from $1.7-21.7$ weight $\%$. Placer concentrations reflect the high degree of mineralogical selection of mature granulometric deposits of shoals. Enriched sands from the Odra Bank contain, as a rule, more than $80 \%$ of the very fine and fine-grained fraction $(0.063-0.25 \mathrm{~mm})$ and are well or very well sorted. A layer enriched with heavy minerals, consists of lamina and streaks, a less laminae thickness of several $\mathrm{cm}$, alternately enriched and poor in heavy minerals. The highest enrichment in heavy minerals is present on the bottom surface and gradually decreases with depth. The enriched layer maximum may reach up to $1 \mathrm{~m}$. The average share of heavy minerals in a layer thickness of $0.5 \mathrm{~m}$ occurring directly from the bottom surface is about $4.5 \%$ and decreases to $2.5-4 \%$ at a depth of $0.5-1 \mathrm{~m}$.

Heavy mineral resources in the sands of A and B fields have been estimated at about 505 thousand tons, including about 25 thousand tons of zirconium, almost 200 thousand tons of titanium minerals (ilmenite, rutile and leucoxene) and about 160 thousand tons of garnets (Kaulbarsz et al. 2013; Kramarska et al. 2016).

\section{The methodology and scope of research}

In this paper, rare earth elements were examined in 7 samples of marine sands, collected from the cores of archive boreholes drilled in the region of the Odra Bank, Słupsk Bank and in two samples from the Hel Peninsula (Fig. 1). Three tagged samples: V201, V210 and V225 come from the subsurface sections of the cores $(0-0.5 \mathrm{~m})$ with the same names, and represent the natural sands with heavy minerals (Fig. 2). Cores were collected with use of a vibro-corer during geological documentation works (Kaulbarsz et al. 2013).

Samples of $\iota O(Z r)$ and $Ł S(Z r)$ come from zirconium concentrates obtained in the processes of enrichment, separation and recovery of heavy minerals from marine sands (Bagdach and Lasko, 1989). The $Ł O(Z r)$ sample constitutes the zirconium concentrate recovered from the sands of the Odra Bank, where sand weighing 1.2 thousand tons contained an average of $1.72 \%$ heavy minerals. While $\mathrm{S}(\mathrm{Zr}$ ) zirconium concentrate sample was made from sands of the Słupsk Bank and primary sand sample weighing 2 thousand tons contained an average of $4.2 \%$ of heavy minerals (ibid.).

The samples with the symbols $\mathrm{He} 1$ and $\mathrm{He} 2$ were collected on the Hel Peninsula from a $16.6 \mathrm{~km}$ stretch of beach. A sample of the sands $(\mathrm{He} 1 ; 10 / 13 / 13)$ was taken from the beach drift (Fig. 2a), and sample (He2; 10/13/14) from the same place but from the score in the trench with a depth of $1 \mathrm{~m}$ (Fig. 2b). The 2 samples mentioned above were the subject of classic panning and heavy mineral concentrates were obtained. The Hel sample of marine 


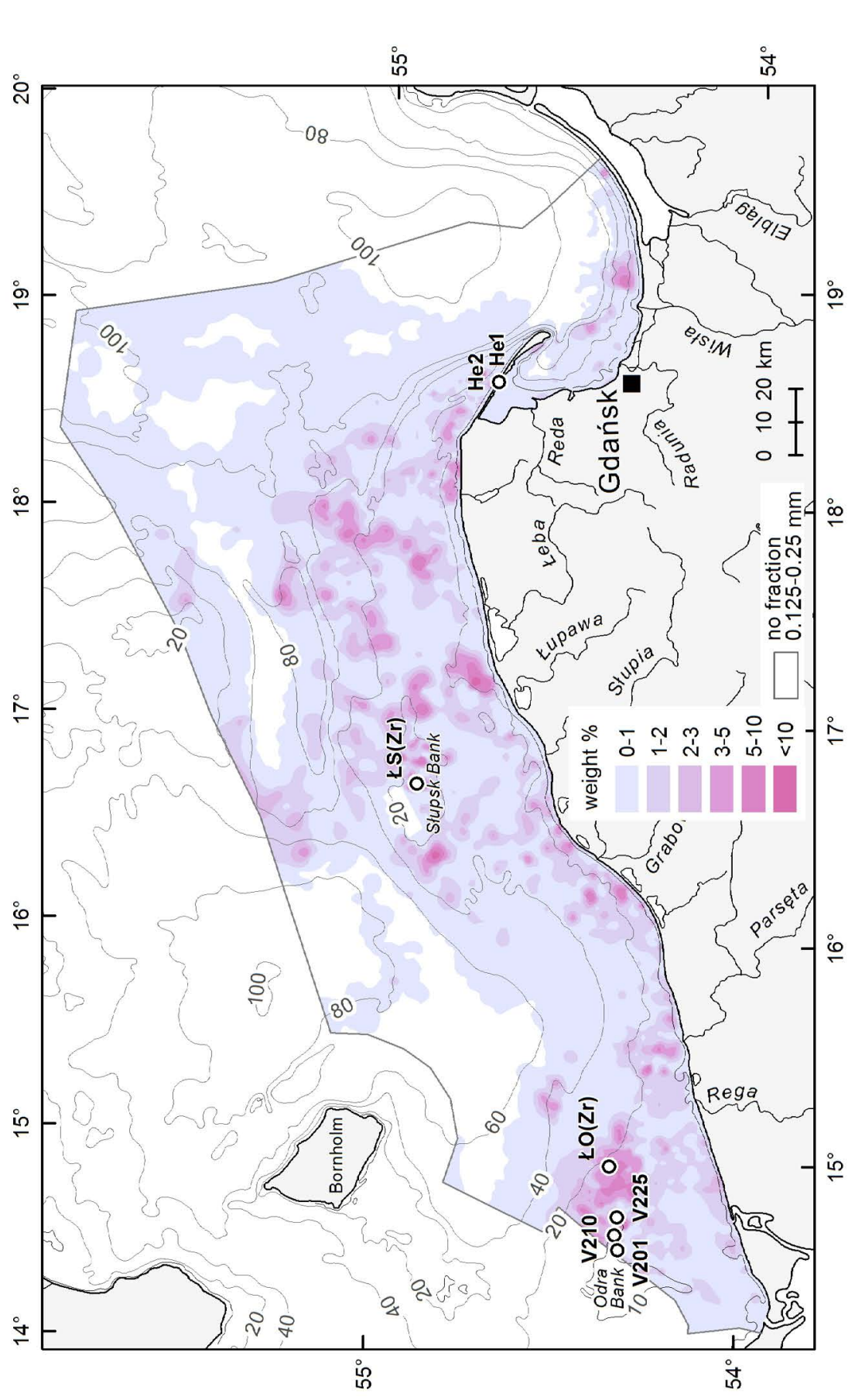



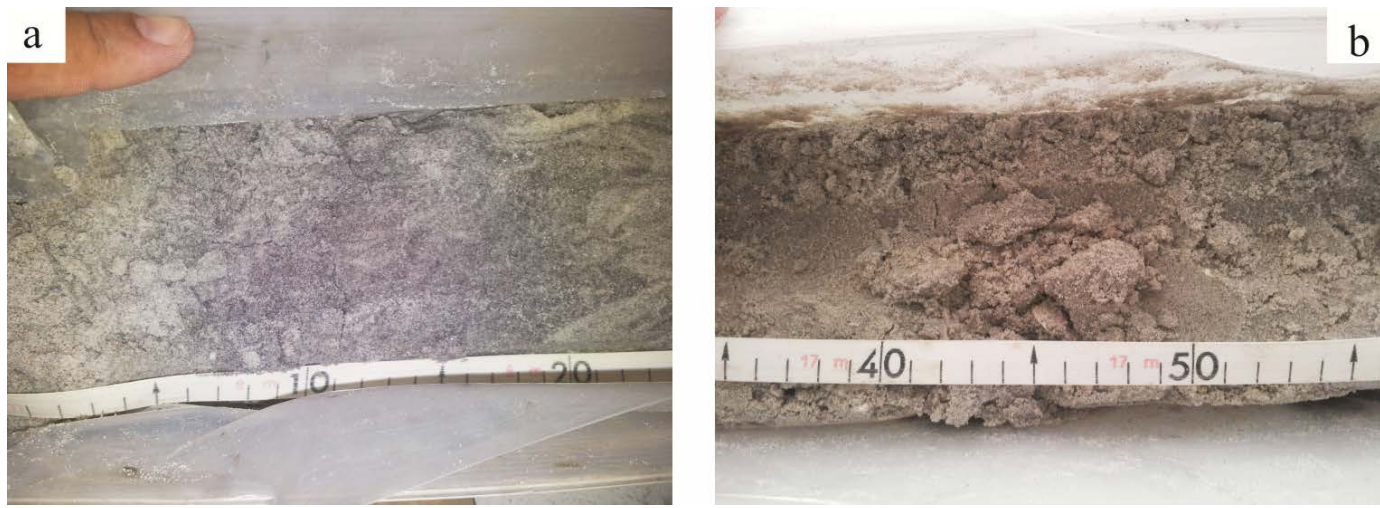

Fig. 2. Marine sands samples enriched in heavy minerals a) V201 borehole, depth 0-0.5 m, b) V210 borehole, depth 0-0.5 m. Odra Bank

Rys. 2. Próbki piasków morskich wzbogacone w minerały ciężkie a) Wiercenie V201, głęb. 0-0,5 m, b) Wiercenie V210, głęb. 0-0,5 m. Ławica Odrzana

sands contained about $30.9 \%$ heavy minerals and He2 sample has only about $0.14 \%$ heavy minerals. All the sand samples were subject of REE analyses.

Rare earth elements, Sc, Y, and Th analyses were performed at the Chemical Laboratory of the Polish Geological Institute - National Research Institute, using mass spectrometry with inductively coupled plasma mass spectrometry (ICP-MS technic). After acid digestion, the samples were diluted 20 times with a solution of $1 \% \mathrm{HNO}_{3}$. The total solution of
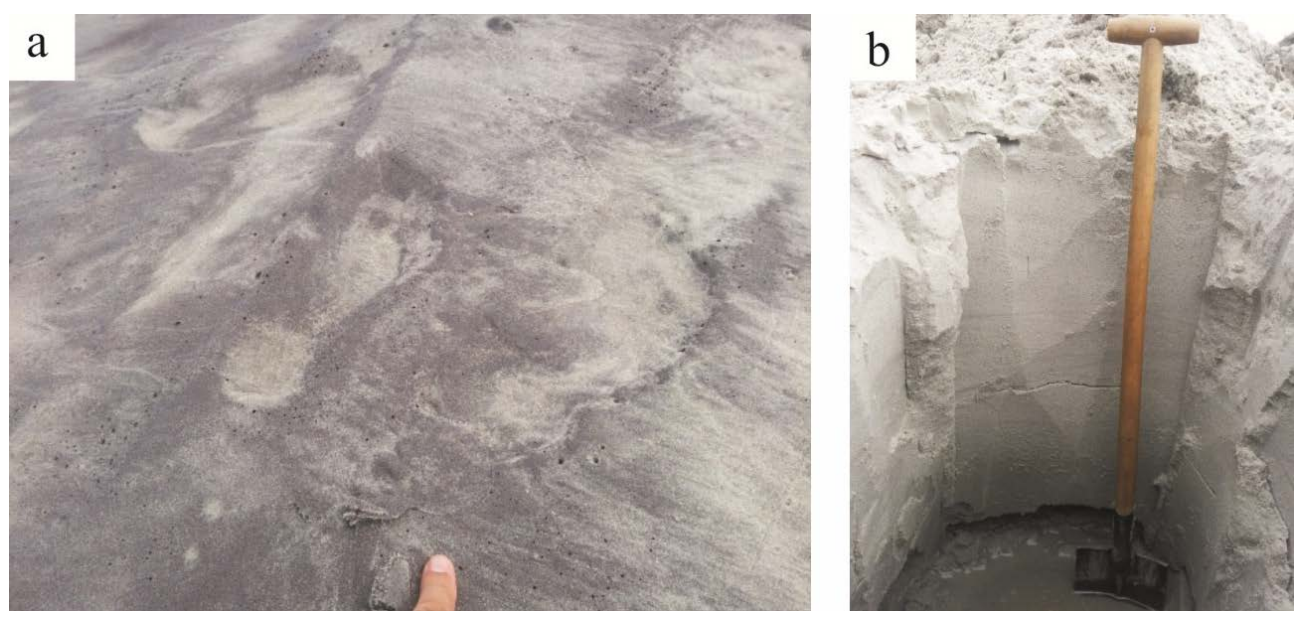

Fig. 3. a) Beach sands from the upper near shore zone enriched in heavy minerals (Hel),

b) Trench in order to collect the profile sample with a width of $5 \mathrm{~cm}$ and a height of ca. $1 \mathrm{~m}(\mathrm{He} 2)$

Rys. 3. a) Piaski plażowe ze strefy przyboju silnie wzbogacone w minerały ciężkie (próbka He1), b) Wkop w celu pobrania próbki bruzdowej o szerokości $5 \mathrm{~cm}$ i wysokości około $1 \mathrm{~m}$ (próbka He2) 
elements contained in the samples was achieved by the use of hydrofluoric acid and chloric acid (VII - oxidation of fluorine and chlorine in acid). Dried and powdered samples were initially treated with nitric acid (V) in order to distribute organic matter and dissolved in a mixture of perchloric and hydrofluoric acid (VII). In order to improve the procedure for dissolution, digestion was repeated three times. In the last stage, after evaporation to dryness (on a hot plate, to a temperature of $150^{\circ} \mathrm{C} \pm 10^{\circ} \mathrm{C}$ ) the residue was dissolved in dilute nitric acid (V). The solution obtained was submitted for analysis by ICP-MS. Detection limits were $0.5 \mathrm{ppm}$ for LREE and $0.05 \mathrm{ppm}$ for HREE.

The concentrates were made from heavy minerals samples and sections were polished for the work under the polarizing microscope (NIKON ECLIPSE LV100 POL) and electron microprobe (CAMECA SX-100). Specifications were as follows: voltage $-15 \mathrm{kV}$, current beam 10, beam focused. Acquisition times: in the peak position- $20 \mathrm{~s}$, the position of the background-10 s. Depositing carbon. The following spectral lines were examined: $\mathrm{Ce}-\mathrm{L} \alpha$, $\mathrm{La}-\mathrm{L} \alpha, \operatorname{Pr}-\mathrm{L} \beta, \mathrm{Nd}-\mathrm{L} \beta, \mathrm{Sm}-\mathrm{L} \beta, \mathrm{Gd}-\mathrm{L} \beta$ and Dy $-\mathrm{L} \alpha$. The lines were selected in order to avoid interference. Analyzed on the crystals type LLIF. Standards: - synthetic glass doped with REE made by P\&H Company.

\section{Results of the rare earths studies in the marine sands of the Baltic Sea enriched in heavy minerals}

\subsection{Odra Bank}

The following V201, V210 and V225 core samples represent fine-grained sands with the dominance of $0.125-0.25 \mathrm{~mm}$ fraction (usually $>70 \%$ ). The main admixture constitutes the $0.25-0.5 \mathrm{~mm}$ fraction, which occurs in quantities from several dozen to about $30 \%$ (Kaulbarsz et al. 2013). The heavy minerals content in samples being the subject of REE analyses belongs to the highest in the entire area of the Odra Bank covered by the resource evaluation. In the trench (profile) samples (V225 and V210) collected from the upper $(0-0.5 \mathrm{~m})$ part of the cores, their content are 4.64 and $6.15 \%$, respectively. The highest contents of heavy minerals (c.a. $21.7 \%$ weight \%) was found in the V201 sample. In a layer from a depth of $0.5-1 \mathrm{~m}$ below the seabed the heavy minerals contents falls below 3 weight $\%$. Research of the 20-centimeter core segments shows a progressive decline in heavy minerals content with the depth

Rare earth elements and thorium were found as a result of the carried out ICP-MS chemical analysis in the all samples (Table 1). Mainly a group of the light lanthanides with a high content of cerium, lanthanum and neodymium occurs in the marine sand samples. The content of yttrium, which in the V201 sample is dominant over the rare earths, is noteworthy. The thorium content is much lower than the listed elements. There is a clear relationship 


\begin{tabular}{|c|c|c|c|c|c|c|c|c|c|}
\hline & $\Xi$ & & $\stackrel{\widetilde{m}}{=}$ & $\stackrel{\infty}{n}$ & oे & 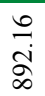 & $\begin{array}{l}\widetilde{0} \\
\infty \\
\stackrel{+}{f}\end{array}$ & $\stackrel{m}{m}$ & 卞 \\
\hline & $\exists$ & & $\stackrel{?}{\stackrel{2}{i}}$ & ช్రా & สิ & in & $\underset{i}{i}$ & $\overrightarrow{0}$ & $\underset{i}{\stackrel{i}{i}}$ \\
\hline & 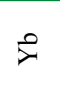 & & $\exists$ & $\begin{array}{l}\infty \\
\infty \\
\infty\end{array}$ & $\underset{\exists}{F}$ & $\begin{array}{l}\infty \\
\stackrel{\text { }}{j}\end{array}$ & $\underset{m}{m}$ & $\overrightarrow{0}$ & $=$ \\
\hline & $\Xi$ & & $\stackrel{t}{n}$ & $\stackrel{+}{n}$ & $\frac{2}{0}$ & $\hat{o}$ & $\underset{\dot{n}}{\hat{n}}$ & $\overrightarrow{0}$ & $\stackrel{+}{i}$ \\
\hline & 轲 & & $\stackrel{\infty}{\circ}$ & $\vec{j}$ & 옥 & $\stackrel{n}{m}$ & $\hat{\mathrm{d}}$ & $\stackrel{\circ}{\circ}$ & $\begin{array}{l}0 \\
\stackrel{0}{\Omega}\end{array}$ \\
\hline & 오 & & ڤે̀ & $\hat{a}$ & ô. & $\overrightarrow{\mathcal{Y}}$ & 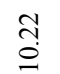 & $\vec{ก}$ & $\hat{s}$ \\
\hline 总 & $\vec{a}$ & & 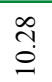 & $\underset{+}{\dot{f}}$ & $\stackrel{\text { N }}{\text { I }}$ & $\frac{0}{9}$ & 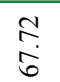 & $\stackrel{\Omega}{-}$ & సู่ \\
\hline 동 & $\ddot{F}$ & & 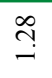 & 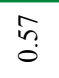 & חָ & $m$ & $\underset{\tilde{n}}{\tilde{n}}$ & $\stackrel{\infty}{\circ}$ & 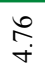 \\
\hline 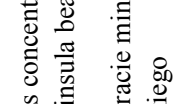 & $\Xi$ & & $\begin{array}{l}\vec{\infty} \\
\dot{i}\end{array}$ & $\stackrel{\tilde{m}}{\dot{m}}$ & $\stackrel{\text { I }}{\text { g }}$ & 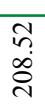 & $\begin{array}{l}\text { הִ } \\
\stackrel{0}{0}\end{array}$ & $\stackrel{\text { II }}{-}$ & $\stackrel{g}{\vec{f}}$ \\
\hline 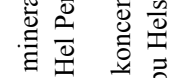 & 島 & 0 & $\stackrel{0}{0}$ & $\stackrel{\text { ริ. }}{0}$ & $\stackrel{\text { İ }}{0}$ & \begin{tabular}{l}
$\infty$ \\
$\infty$ \\
\hdashline
\end{tabular} & $\stackrel{?}{q}$ & İ & $\underset{\mathrm{T}}{\mathrm{T}}$ \\
\hline 褪 & है & & $\widehat{\hat{A}}$ & స్లి & $\underset{i}{d}$ & oे & 㞼 & $\stackrel{\infty}{\stackrel{\infty}{-}}$ & fóf \\
\hline 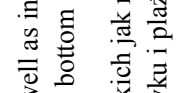 & $\vec{z}$ & & $\stackrel{?}{d}$ & ن̊. & $\stackrel{m}{=}$ & i̊ & $\begin{array}{l}n \\
\vdots \\
0\end{array}$ & $\stackrel{\infty}{\sim}$ & ڤ్ సి \\
\hline 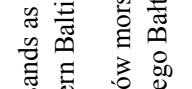 & $\Xi$ & & तु & $\stackrel{\text { I }}{f}$ & $\stackrel{\circ}{\circ}$ & ڤें & نें & $\sim$ & $\underset{\infty}{+}$ \\
\hline 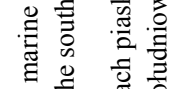 & $\ddot{U}$ & & $\stackrel{r}{\dot{n}}$ & 芦 & ?ֶ. & $\stackrel{\vec{S}}{\vec{S}}$ & $\begin{array}{l}\stackrel{n}{+} \\
\stackrel{+}{\sim}\end{array}$ & $\stackrel{\infty}{\beth}$ & 8 \\
\hline 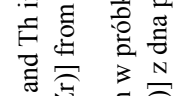 & $\stackrel{\Xi}{\lrcorner}$ & & $\stackrel{n}{n}$ & $\stackrel{\infty}{\stackrel{\infty}{\omega}}$ & $\stackrel{\Xi}{\mathrm{I}}$ & $\vec{z}$ & $\begin{array}{l}\infty \\
\\
n\end{array}$ & $\underset{\infty}{+}$ & ৯े \\
\hline 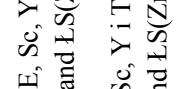 & $\succ$ & & 8 & $\begin{array}{l}0 \\
\ddot{a}\end{array}$ & $\hat{a}$ & i্j & 芯 & $\stackrel{n}{n}$ & $\stackrel{ \pm}{ \pm}$ \\
\hline كِ & $\ddot{\mathscr{L}}$ & & $\ddot{\gamma}$ & $\stackrel{9}{r}$ & $\stackrel{\sim}{n}$ & $\stackrel{\text { 于 }}{ \pm}$ & ì & $\stackrel{\sim}{工}$ & $\stackrel{\infty}{\sim}$ \\
\hline 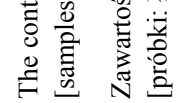 & $\begin{array}{l}\text { 禽 } \\
\text { 岗 }\end{array}$ & & 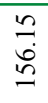 & ๙̊̀ & लिं & $\underset{\infty}{\infty}$ & 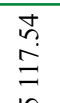 & 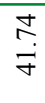 & $\underset{m}{\stackrel{0}{+}}$ \\
\hline$\frac{\dot{\pi}}{\frac{\pi}{0}}$ & 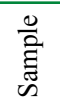 & 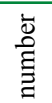 & $\overrightarrow{\mathrm{i}}$ & $\stackrel{\circ}{\stackrel{S}{S}}$ & 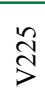 & 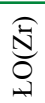 & 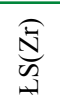 & $\vec{\Xi}$ & $\stackrel{\widetilde{N}}{\tilde{I}}$ \\
\hline
\end{tabular}



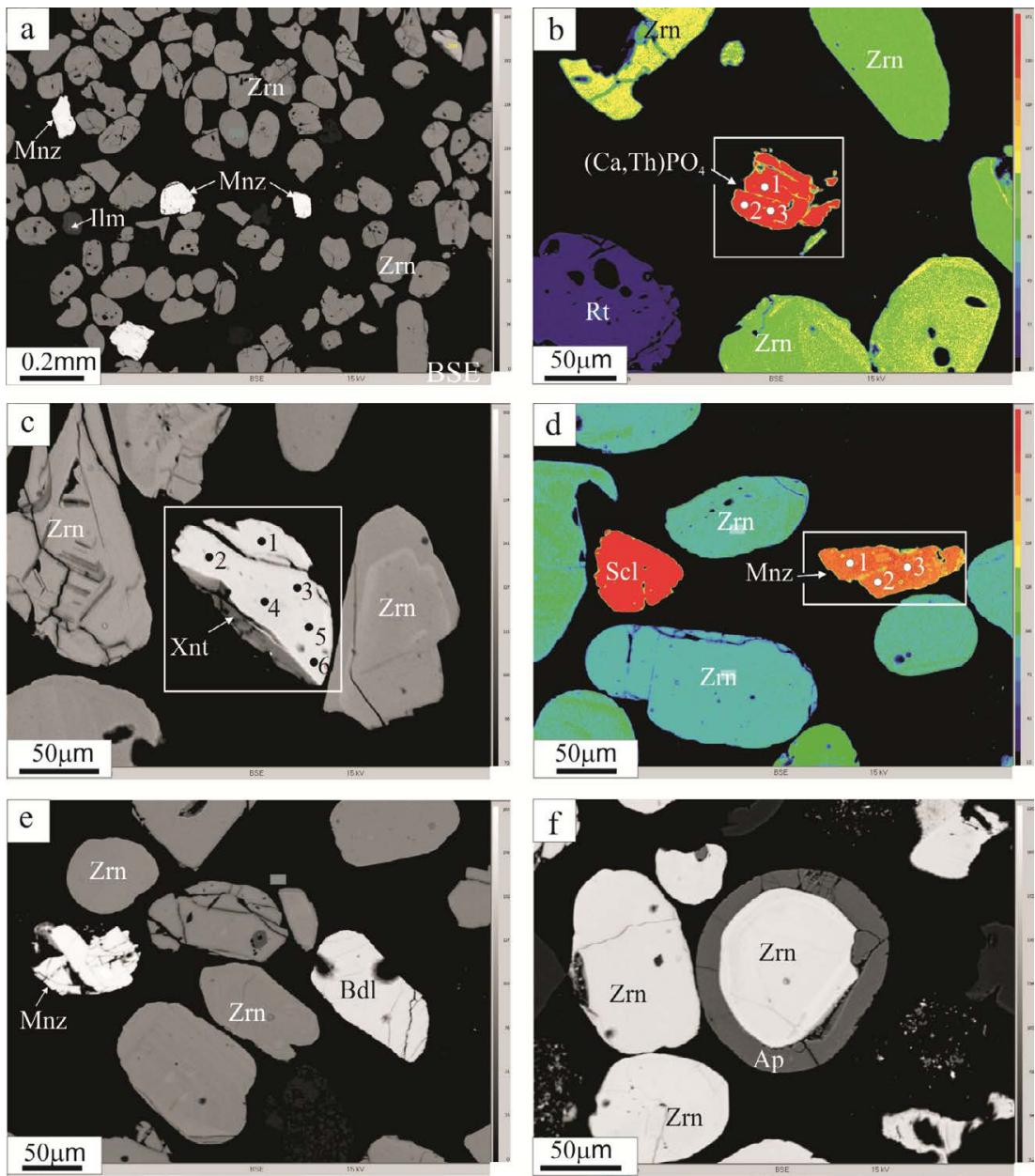

Fig. 4. The heavy minerals concentrate from the Odra Bank with visible well-rounded grains. Sample no. LO/P-4 a) Zircon grains dominate among minerals in the concentrate (Zrn; darkgrey). Monazite grains (Mnz; white) are subordinate and ilmenite (Ilm) appears as single grains. Back-Scattered Electron Image (BSEI) /field 01/photo-1 see Table 2, b) BSEI in artificial colors reveals different minerals in heavy minerals concentrate; $(\mathrm{Ca}, \mathrm{Th}) \mathrm{PO} 4$ - Th apatite; Rt - rutile; Zrn - zircon, c) Grains of zircon (Zrn) and xenotime (Xnt) with visible point of SEM analyses. BSEI/field 04/photo-2, d) BSEI in artificial colors reveals different minerals in heavy minerals concentrate; Scl - scheelite; Zrn - zircon; Mnz - monazite. BSEI/field 02/photo-2, e) Well-rounded zircon grains (Zrn) together with baddeleyite (Bdl) and monazite (Mnz). BSEI. Grain of zircon (Zrn) with apatite (Ap) rim. BSEI

Rys. 4. Koncentrat minerałów ciężkich z Ławicy Odrzanej z widocznym dobrym obtoczeniem ziarn. Próbka nr LO/P-4 a) Ziarna cyrkonu dominują ilościowo w koncentracie minerałów ciężkich (Zrn; ciemnoszary). Ziarna monacytu (Mnz; biały) są ilościowo podrzędne i podobnie jak ilmenit (Ilm) występują jako pojedyncze

ziarna. Obraz elektronów wstecznie odbitych (BSEI) /obszar 01/foto-1 patrz tab. 2, b) Obraz elektronów wstecznie odbitych w sztucznych barwach uwypukla różnice w obecności minerałów w koncentracie; $(\mathrm{Ca}, \mathrm{Th})$ PO4 - Th apatyt; Rt - rutyl; Zrn - cyrkon, c) Ziarna cyrkonu (Zrn) i ksenotymu (Xnt) z widocznymi punktami analiz SEM. BSEI/obszar 04/foto-2, d) BSEI w sztucznych barwach uwypukla różnice w obecności minerałów w koncentracie; Scl - scheelite; Zrn - cyrkon; Mnz - monacyt. BSEI/obszar 02/foto-2, e) Dobrze obtoczone ziarna cyrkonu (Zrn) w towarzystwie z baddeleyitem (Bdl) i monacytem (Mnz). BSEI. Ziarno cyrkonu (Zrn) $z$ otoczką apatytu (Ap). BSEI 
of the REE content with the presence of heavy minerals in sediments. The highest concentrations of rare earth elements are present in the V201 sample, which has c.a. 21.7 weight $\%$ of heavy minerals. They are most often 2-3 times higher than in V210 and V225 samples.

Zircon dominates in the heavy minerals concentrate $(€ O(\mathrm{Zr})$ and the contents of rare earth elements is many times higher (even 100 times) than in the natural marine sands. The light lanthanides also dominate in the zircon concentrate sample $Ł O(Z r)$. The cerium concentration reaches $3.9 \mathrm{~g} / \mathrm{kg}$, and lanthanum and neodymium occur in the amount of 1.9 and $1.7 \mathrm{~g} / \mathrm{kg}$. The contents of praseodymium, yttrium, gadolinium and samarium are in the range of $0.5-0.2 \mathrm{~g} / \mathrm{kg}$. Components of the subgroups of heavy lanthanides are in the range from several to almost $100 \mathrm{mg} / \mathrm{kg}$. In relation to the contents of the lanthanides in comparison to their content in sand samples, the content of yttrium is low $(332 \mathrm{mg} / \mathrm{kg})$ and scandium $(14.7 \mathrm{mg} / \mathrm{kg})$ was negligible. However, thorium reaches almost $0.9 \mathrm{~g} / \mathrm{kg}$ of concentrate. Microscopic and microprobe research revealed a concentrate of the dominant presence of zircon in the $\mathrm{LO}(\mathrm{Zr})$ sample and also the appearance other heavy minerals such as garnet, topaz, rutile or apatite (in total of up to a dozen percent volume of concentrate). Zircons are well rounded and generally have sizes c.a. of $100 \mu \mathrm{m}$ in length (range from 80 to $150 \mu \mathrm{m}$ ). They show different content for $\mathrm{Hf}$ and a varied admixture of yttrium. monazites which are the main media of LREEO (55-60 weight \%) and Th (c.a. 3-8 weight \%; Table 2) have up to several percent in concentrate. Monazites, like zircons are well rounded and the sizes of the grains are in the range from 100 to $250 \mu \mathrm{m}$ (Fig. 4a, 4d-e). Xenotime single well-rounded grains are up to $100 \mu \mathrm{m}$ in diameter (Fig. 4c) and apatite grains were also found (Fig. 4b). Apatite grains are slightly smaller in size (50-70 $\mu \mathrm{m}$ in diameter) and may form very spectacular rims around the zircon core (Fig. 4f). It's a variety rich in thorium occurs among apatite (up to 47.6 weight $\% \mathrm{Th}$; Table 3). Xenotime has a high yttrium contents (43-44 weight $\%$ of $\mathrm{Y}_{2} \mathrm{O}_{3}$ ) and an admixture of HREEO (sum $>15$ weight $\%$; Table 3). Rutile (without $\mathrm{Nb}$-additives), and ilmenite also occur in heavy concentrations, however in subordinate quantities. Single grains of baddeleyite or scheelite (with a diameter of approx. $70 \mu \mathrm{m}$ ) were also found (Fig. $4 \mathrm{~d}-\mathrm{e}$ ).

\subsection{Slupsk Bank}

The light lanthanides also dominate in the heavy minerals concentrate of the $\operatorname{LS}(\mathrm{Zr})$ sample from the Słupsk Bank. The cerium concentration reaches $2.3 \mathrm{~g} / \mathrm{kg}$, and lanthanum and neodymium is present in the amount of 1.1 and $0.96 \mathrm{~g} / \mathrm{kg}$, respectively (Table 1). Praseodymium, yttrium, gadolinium and samarium occur in contents from 0.1 to $0.3 \mathrm{~g} / \mathrm{kg}$. Components of the subgroups of heavy lanthanides are in the range of several (Lu, Tm) to almost $68 \mathrm{mg} / \mathrm{kg}$ (Dy). Compared with the sand samples, there is a low content of yttrium $(276 \mathrm{mg} / \mathrm{kg})$ and negligible of scandium $(15.9 \mathrm{mg} / \mathrm{kg})$ in relation to the other lanthanides. However, thorium reaches nearly $0.5 \mathrm{~g} / \mathrm{kg}$ in the concentrate. 


\begin{tabular}{|c|c|c|c|c|c|c|c|c|c|c|c|c|c|c|c|c|c|c|c|c|c|c|c|}
\hline \begin{tabular}{|l|}
$\frac{1}{0}$ \\
$\frac{0}{2}$
\end{tabular} & $\vec{m}$ & $\begin{array}{l}0 \\
\vdots \\
0\end{array}$ & $\mid \begin{array}{l}0 \\
\vdots \\
0 \\
0\end{array}$ & $\mid \begin{array}{l}\tilde{\sigma} \\
\hat{\sigma}\end{array}$ & $\begin{array}{l}0 \\
0 \\
0 \\
0\end{array}$ & 年 & $\mid \begin{array}{l}0 \\
0 \\
0 \\
0 \\
0\end{array}$ & 8 & $\begin{array}{l}n \\
\frac{n}{7} \\
0 \\
0\end{array}$ & $\mid \begin{array}{c}\tilde{\lambda} \\
\\
\end{array}$ & 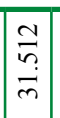 & $\overrightarrow{\grave{i}}$ & $\mid$ & $\mid$ & 0 & $\begin{array}{l}\sigma \\
\hat{\sigma}\end{array}$ & สิ & $\begin{array}{l}0 \\
0 \\
0 \\
0\end{array} \mid$ & $\left|\begin{array}{l}n \\
\vdots \\
f \\
i\end{array}\right|$ & $\mid \begin{array}{l}1 \\
0 \\
? \\
0 \\
0\end{array}$ & 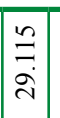 & 0 & \\
\hline 然 & $\bar{\lambda}$ & $\begin{array}{l}\infty \\
0 \\
0 \\
0\end{array}$ & 0 & \begin{tabular}{|l|}
$\vec{\partial}$ \\
\end{tabular} & 0 & $\hat{\tilde{c}}$ & 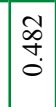 & ठ্] & 茂 & 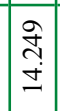 & $\mid \begin{array}{c}\tilde{y} \\
\dot{m} \\
\dot{m}\end{array}$ & $\begin{array}{l}0 \\
0 \\
\infty \\
i \\
i\end{array}$ & $\stackrel{\bullet}{\stackrel{0}{=}}$ & $\underset{f}{\stackrel{f}{f}}$ & 0 & $\begin{array}{l}\stackrel{\partial}{\partial} \\
\stackrel{0}{0}\end{array}$ & $\begin{array}{l}n \\
\stackrel{m}{0} \\
0\end{array}$ & 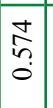 & $\left.\mid \begin{array}{l}\infty \\
0 \\
6 \\
i\end{array}\right]$ & $\mid$\begin{tabular}{c}
$\mathcal{I}$ \\
\multirow{Z}{0}{} \\
0
\end{tabular} & 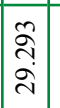 & 0 & \\
\hline 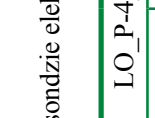 & $\Xi$ & $\begin{array}{l}\infty \\
\vdots \\
0 \\
0\end{array}$ & $\mid \begin{array}{c}\tilde{\delta} \\
0 \\
0\end{array}$ & $\mid \begin{array}{l}\hat{1} \\
\hat{a} \\
0\end{array}$ & $\mid \begin{array}{l}\varkappa \\
0 \\
0\end{array}$ & 0 & $\mid \begin{array}{l}\vec{\alpha} \\
\stackrel{0}{0} \\
0\end{array}$ & ठ̃ & कृ & $\mid \begin{array}{c}\tilde{\partial} \\
\dot{\Xi} \\
\dot{ \pm}\end{array}$ & $\frac{f}{f}$ & $\begin{array}{l}\hat{\alpha} \\
i\end{array}$ & 亭 & 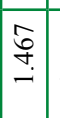 & 0 & $\mid \begin{array}{l}\mathfrak{n} \\
\hat{a} \\
0 \\
0\end{array}$ & $\begin{array}{l}\stackrel{0}{\circ} \\
0 \\
0\end{array}$ & $\begin{array}{l}\overrightarrow{\widehat{n}} \\
0\end{array}$ & $\mid \begin{array}{c}a \\
\dot{a} \\
\dot{c} \\
\dot{w}\end{array}$ & : & \begin{tabular}{|l}
0 \\
0 \\
0 \\
0 \\
$\vdots$ \\
2
\end{tabular} & 0 & \\
\hline 竞 & $\bar{m}$ & $\begin{array}{l}\tau \\
\stackrel{0}{0} \\
0\end{array}$ & $\mid \begin{array}{l}\vec{\delta} \\
\dot{0}\end{array}$ & $\mid \begin{array}{c}0 \\
n \\
0 \\
0\end{array}$ & 0 & $\mid \begin{array}{l}\infty \\
\stackrel{0}{0}\end{array}$ & $\begin{array}{l}\infty \\
\text { ते } \\
0\end{array}$ & 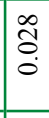 & ô & $\begin{array}{l}\overrightarrow{0} \\
\dot{b} \\
.\end{array}$ & $\begin{array}{l}\stackrel{n}{\prime} \\
\stackrel{m}{m} \\
\end{array}$ & $\begin{array}{l}\hat{a} \\
\hat{i} \\
\vec{i}\end{array}$ & \begin{tabular}{|l|}
$\vec{t}$ \\
$n$ \\
0 \\
0
\end{tabular} & $\mid \begin{array}{c}\stackrel{\partial}{-} \\
- \\
-\end{array}$ & 0 & $\begin{array}{l}\stackrel{1}{\vec{R}} \\
\stackrel{0}{0}\end{array}$ & $\frac{\overrightarrow{0}}{0}$ & $\begin{array}{c}1 \\
\vdots \\
0 \\
0\end{array} \mid$ & \begin{tabular}{|c|}
$\infty$ \\
$\stackrel{\infty}{\infty}$ \\
$\dot{m}$
\end{tabular} & \begin{tabular}{l|}
0 \\
$\stackrel{0}{0}$ \\
0
\end{tabular} & 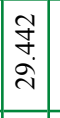 & 0 & \\
\hline 离 & $\sum_{\lambda}$ & $\begin{array}{l}1 \\
0 \\
0\end{array}$ & $\mid \begin{array}{l}0 \\
0 \\
0 \\
0\end{array}$ & $\left|\begin{array}{c}\hat{\lambda} \\
\hat{0}\end{array}\right|$ & 0 & 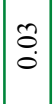 & $\begin{array}{l}2 \\
\stackrel{2}{0} \\
\tilde{o} \\
0\end{array}$ & 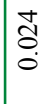 & $\frac{\partial}{\partial}$ & $\mid \begin{array}{l}t \\
\\
\underline{n}\end{array}$ & 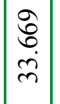 & $\vec{i}$ & \begin{tabular}{l}
$\infty$ \\
\hdashline \\
0 \\
0
\end{tabular} & 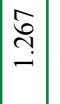 & 0 & $\begin{array}{l}\hat{i} \\
0\end{array}$ & $\begin{array}{l}\stackrel{n}{\vec{c}} \\
\stackrel{0}{0}\end{array}$ & $\begin{array}{l}0 \\
f \\
0 \\
0 \\
0\end{array}$ & $\begin{array}{c}\infty \\
m \\
m \\
m\end{array}$ & $\stackrel{-}{0}$ & $\mid$\begin{tabular}{|l}
$\vec{\infty}$ \\
0 \\
0 \\
$\hat{i}$
\end{tabular} & $\begin{array}{l}\tilde{N} \\
\tilde{0} \\
0 \\
0\end{array}$ & \\
\hline $\begin{array}{l}a_{1} \\
0^{\prime} \\
\end{array}$ & $\Xi$ & $\mid \begin{array}{l}\infty \\
0 \\
0 \\
0\end{array}$ & $\mid \begin{array}{l}0 \\
\dot{\partial} \\
\dot{0}\end{array}$ & $\mid \begin{array}{c}0 \\
\vdots \\
\vdots \\
0\end{array}$ & 0 & 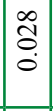 & $\mid \begin{array}{l}n \\
0 \\
0 \\
0 \\
0\end{array}$ & : & $\stackrel{\partial}{-}$ & $\begin{array}{l}\tilde{n} \\
\stackrel{2}{a} \\
-2\end{array}$ & \begin{tabular}{|c|}
2 \\
$b$ \\
$n$ \\
$m$ \\
$m$
\end{tabular} & $\begin{array}{l}\stackrel{n}{c} \\
i \\
i\end{array}$ & 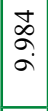 & $\mid \begin{array}{c}2 \\
0 \\
-1 \\
-1\end{array}$ & 0 & $\mid \begin{array}{l}\stackrel{P}{t} \\
\stackrel{0}{0}\end{array}$ & 苍 & $\begin{array}{l}n \\
\vdots \\
0\end{array}$ & \begin{tabular}{|c|}
$\stackrel{m}{\rho}$ \\
$\dot{m}$
\end{tabular} & 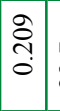 & $\stackrel{\vec{i}}{\vec{i}}$ & 0 & \\
\hline 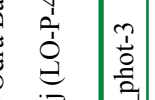 & $\bar{m}$ & 0 & $\mid \begin{array}{c}0 \\
0 \\
0\end{array}$ & 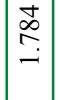 & 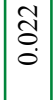 & $\mid \begin{array}{l}0 \\
0 \\
0 \\
0\end{array}$ & & 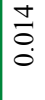 & त̂̃ & 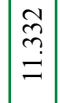 & $\mid$ & $\begin{array}{l}\bar{t} \\
i \\
i\end{array}$ & $\begin{array}{l}n \\
n \\
0 \\
0\end{array}$ & $\mid \begin{array}{c}\hat{A} \\
\infty \\
\stackrel{-}{-}\end{array}$ & 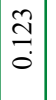 & $\mid \begin{array}{c}\vec{b} \\
\stackrel{\sigma}{-}\end{array}$ & $\begin{array}{l}n \\
i \\
0\end{array}$ & 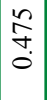 & 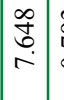 & $\mid \begin{array}{l}0 \\
\hat{\imath} \\
0\end{array}$ & \begin{tabular}{|l|}
$\vec{F}$ \\
$\partial$ \\
$\dot{\lambda}$
\end{tabular} & $\begin{array}{l}n \\
0 \\
0 \\
0\end{array}$ & \\
\hline 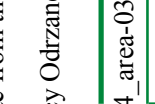 & $\underset{\sim}{\approx}$ & 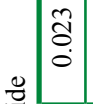 & $\mid \begin{array}{l}\overrightarrow{0} \\
\dot{0}\end{array}$ & 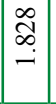 & 0 & 0 & $\begin{array}{l}\infty \\
\infty \\
0\end{array}$ & 0 & 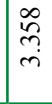 & 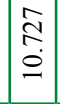 & 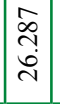 & $\begin{array}{l}\hat{\sigma} \\
i \\
\text { in }\end{array}$ & 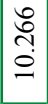 & 常 & 0 & $\begin{array}{l}0 \\
\stackrel{0}{0} \\
- \\
-\end{array}$ & $\begin{array}{c}\infty \\
0 \\
0 \\
0 \\
0\end{array}$ & $\begin{array}{l}\overrightarrow{7} \\
0 \\
0\end{array}$ & 官 & 吕 & 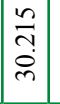 & $\begin{array}{l}\tilde{D} \\
\stackrel{0}{0}\end{array}$ & \\
\hline 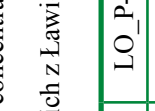 & 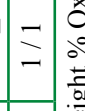 & 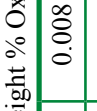 & $\begin{array}{l}2 \\
0 \\
0 \\
0\end{array}$ & 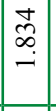 & $\begin{array}{l}0 \\
0 \\
0 \\
0\end{array}$ & $\mid \begin{array}{c}\vec{o} \\
\dot{0}\end{array}$ & $\begin{array}{c}\tilde{C} \\
\hat{\infty} \\
0 \\
0\end{array}$ & 0 & $\begin{array}{l}+ \\
\dot{\sigma} \\
\dot{r}\end{array}$ & $\mid \begin{array}{c}0 \\
\\
\\
\varrho\end{array}$ & 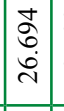 & $\begin{array}{l}\tilde{N} \\
\tilde{n} \\
\end{array}$ & 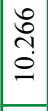 & 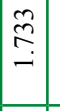 & 0 & 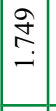 & $\begin{array}{l}n \\
0 \\
0 \\
0 \\
0\end{array}$ & $\begin{array}{c}\text { हे } \\
\text { రై }\end{array}$ & 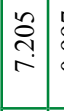 & $\hat{\alpha}$ & \begin{tabular}{|l|} 
\\
\\
$\tilde{n}$ \\
$\stackrel{n}{2}$ \\
\end{tabular} & $\begin{array}{l}\tilde{\sigma} \\
\text { o. }\end{array}$ & \\
\hline 8 & $\overrightarrow{+}$ & 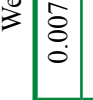 & 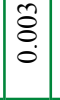 & 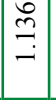 & $\mid \begin{array}{l}0 \\
\stackrel{\Delta}{0} \\
0\end{array}$ & 0 & 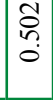 & $\vec{\delta}$ & $\stackrel{m}{=}$ & 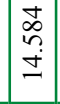 & $\mid \begin{array}{c}\tilde{n} \\
\hat{i} \\
\stackrel{i}{i}\end{array}$ & 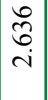 & 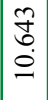 & $\mid \begin{array}{l}\stackrel{n}{a} \\
\stackrel{f}{-} \\
-\end{array}$ & 0 & $\mid \begin{array}{l}\infty \\
\stackrel{0}{0} \\
\stackrel{-}{-}\end{array}$ & 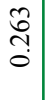 & $\begin{array}{l}\overrightarrow{7} \\
\dot{f} \\
0\end{array}$ & $\mid$ & $\frac{8}{9}$ & $\begin{array}{l}m \\
\infty \\
\dot{i} \\
\dot{\lambda}\end{array}$ & $\begin{array}{l}\hat{0} \\
\stackrel{0}{0} \\
0\end{array}$ & \\
\hline$\stackrel{\circ}{\circ}$ & $\bar{m}$ & \begin{tabular}{l}
0 \\
$\vdots$ \\
$\circ$ \\
\hdashline
\end{tabular} & $\vec{\delta}$ & $\stackrel{?}{\stackrel{P}{-}}$ & $\begin{array}{c}0 \\
0 \\
0 \\
0\end{array}$ & $\overrightarrow{0}$ & $\mid \begin{array}{l}n \\
n \\
n \\
0\end{array}$ & $\stackrel{\partial}{\partial}$ & 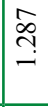 & $\begin{array}{l}\hat{E} \\
\tilde{7} \\
\stackrel{ \pm}{-}\end{array}$ & 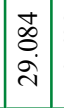 & $\begin{array}{l}\infty \\
\vdots \\
\dot{0} \\
i\end{array}$ & $\begin{array}{l}\bar{n} \\
\text { o. } \\
0\end{array}$ & 官 & 0 & $\stackrel{\widehat{I}}{\rightarrow}$ & $\begin{array}{l}0 \\
\infty \\
0 \\
0 \\
0\end{array}$ & 高 & $\begin{array}{l}\tilde{n} \\
\hat{\sigma} \\
i n\end{array}$ & \begin{tabular}{l}
$\stackrel{2}{\circ}$ \\
\hdashline \\
\end{tabular} & \begin{tabular}{|l|} 
\\
$\infty$ \\
$\dot{\lambda}$ \\
\end{tabular} & & \\
\hline$\tilde{z}$ & $\vec{\Delta}$ & $\begin{array}{l}m \\
0 \\
0 \\
0\end{array}$ & $\mid \begin{array}{l}0 \\
0 \\
0 \\
0\end{array}$ & 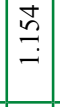 & $\mid \begin{array}{l}0 \\
\grave{0} \\
0\end{array}$ & $\mid \begin{array}{l}\infty \\
\stackrel{0}{0} \\
0\end{array}$ & 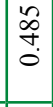 & ¿ू. & 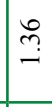 & 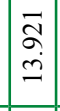 & $\left|\begin{array}{c}\overrightarrow{\hat{c}} \\
\dot{\alpha} \\
i\end{array}\right|$ & {$\left[\begin{array}{c}\infty \\
\infty \\
\infty \\
i\end{array}\right]$} & 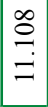 & 芯 & 0 & $\stackrel{\stackrel{\sim}{m}}{-}$ & 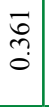 & $\begin{array}{l}0 \\
\stackrel{0}{n} \\
0 \\
0\end{array}$ & \begin{tabular}{|l} 
\\
aे \\
in
\end{tabular} & 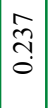 & $\begin{array}{l}n \\
\bar{n} \\
\grave{i}\end{array}$ & o & \\
\hline & & $\begin{array}{l}0 \\
0 \\
0 \\
0\end{array}$ & ठै. & $\mid \begin{array}{l}\mathscr{0} \\
\stackrel{\leftrightarrow}{-}\end{array}$ & 0 & $\mid \begin{array}{r}\tilde{\delta} \\
\dot{0}\end{array}$ & 年 & 0 & $\underset{\widetilde{Y}}{\bar{\tau}}$ & 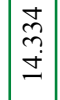 & $\left|\begin{array}{l}\infty \\
\infty \\
\infty \\
\infty \\
i \\
i\end{array}\right|$ & $\begin{array}{l}m \\
\grave{o} \\
i\end{array}$ & 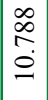 & $\mid$ & 0 & $\stackrel{\vec{m}}{\stackrel{m}{-}}$ & 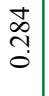 & ते & $\left|\begin{array}{c}n \\
a \\
i n\end{array}\right|$ & $\begin{array}{c}\hat{\infty} \\
\stackrel{0}{0}\end{array}$ & $\mid \begin{array}{l}\infty \\
0 \\
\vdots \\
\vdots \\
i\end{array}$ & & \\
\hline & $\frac{F}{m}$ & $\vec{\Xi}$ & $\overrightarrow{\bar{\sigma}}$ & $\mid \begin{array}{c}\text { ָ̦ } \\
-\end{array}$ & 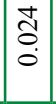 & 0 & $\begin{array}{l}\hat{\tilde{o}} \\
\dot{0} \\
0\end{array}$ & 0 & 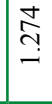 & $\mid \begin{array}{l}n \\
0 \\
\dot{m} \\
\end{array}$ & $\mid \begin{array}{l}\infty \\
\infty \\
0 \\
\infty \\
\infty \\
\\
\end{array}$ & $\begin{array}{l}0 \\
\stackrel{1}{t} \\
i\end{array}$ & 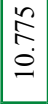 & సે & $\mid \begin{array}{l}0 \\
0 \\
0 \\
0\end{array}$ & 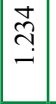 & $\begin{array}{c}\frac{\infty}{3} \\
\overrightarrow{0}\end{array}$ & $\begin{array}{l}\infty \\
\infty \\
= \\
=\end{array}$ & $\begin{array}{l}\hat{D} \\
0 \\
\infty \\
\infty\end{array}$ & $\mid \begin{array}{l}\infty \\
0 \\
0 \\
0\end{array}$ & \begin{tabular}{|l|}
$q$ \\
2 \\
$o$ \\
$i$ \\
$i$
\end{tabular} & 0 & \\
\hline & $\underset{\lambda}{\bar{N}}$ & 离 & 0 & 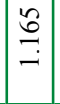 & 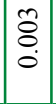 & $\mid \begin{array}{l}n \\
0 \\
0 \\
0\end{array}$ & 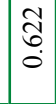 & $\stackrel{0}{0}$ & ले & 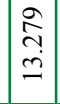 & $\begin{array}{l}\hat{\sigma} \\
\stackrel{\sim}{\sim}\end{array}$ & $\begin{array}{l}\infty \\
\infty \\
\infty \\
\infty\end{array}$ & 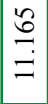 & $\begin{array}{l}\mathscr{q} \\
\stackrel{\tilde{g}}{-} \\
-\end{array}$ & $\vec{\partial}$ & 忞 & స్ & $\begin{array}{l}\infty \\
\vdots \\
0\end{array}$ & $\mid \begin{array}{l}0 \\
0 \\
0 \\
\infty\end{array}$ & 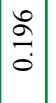 & $\mid \begin{array}{l}\infty \\
0 \\
0 \\
\vdots \\
i\end{array}$ & & \\
\hline$\therefore$ & - & 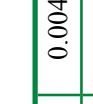 & $\mid \begin{array}{c}\tilde{o} \\
0 \\
0\end{array}$ & $\begin{array}{l} \pm \\
\stackrel{D}{=} \\
=\end{array}$ & 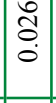 & 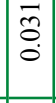 & & \& & 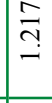 & 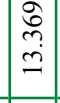 & 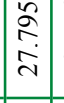 & ڤn & \begin{tabular}{|l}
$\frac{\pi}{2}$ \\
$\stackrel{\theta}{\Theta}$
\end{tabular} & $\mid$\begin{tabular}{c}
0 \\
0 \\
$n$ \\
\hdashline
\end{tabular} & 0 & $\stackrel{\stackrel{\vartheta}{\beth}}{=}$ & $\frac{d}{d}$ & פे & 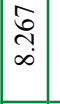 & $\mid \begin{array}{l}\infty \\
\infty \\
0 \\
0\end{array}$ & 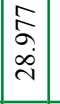 & & \\
\hline & & & & & 考 & & & & & | & 0 & & & है & $\mid$ & $\left|\begin{array}{l}0 \\
\mathbb{J}^{N} \\
\mathbb{S}^{\prime}\end{array}\right|$ & & & $\stackrel{\Xi}{F}$ & & & & \\
\hline
\end{tabular}




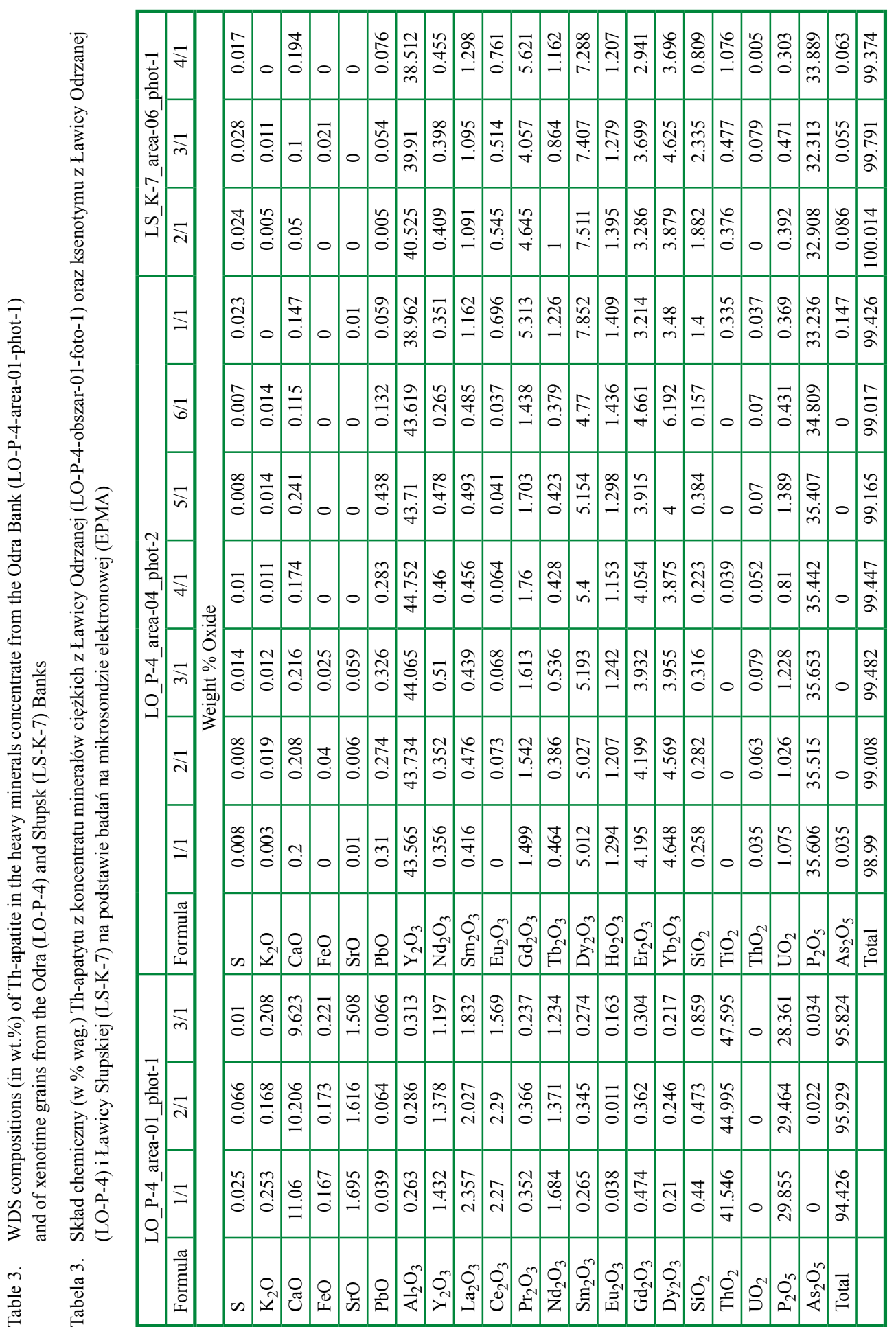




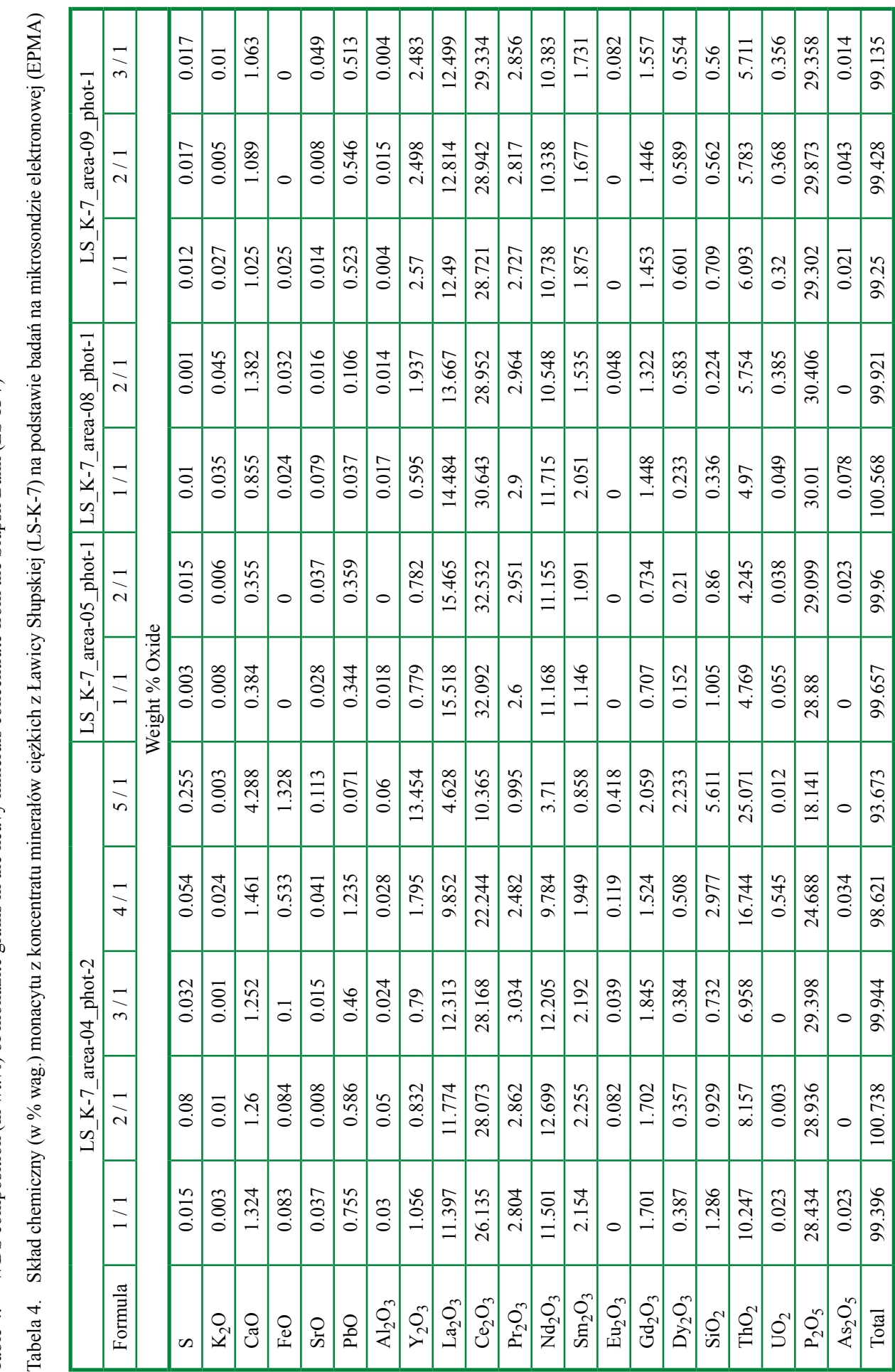



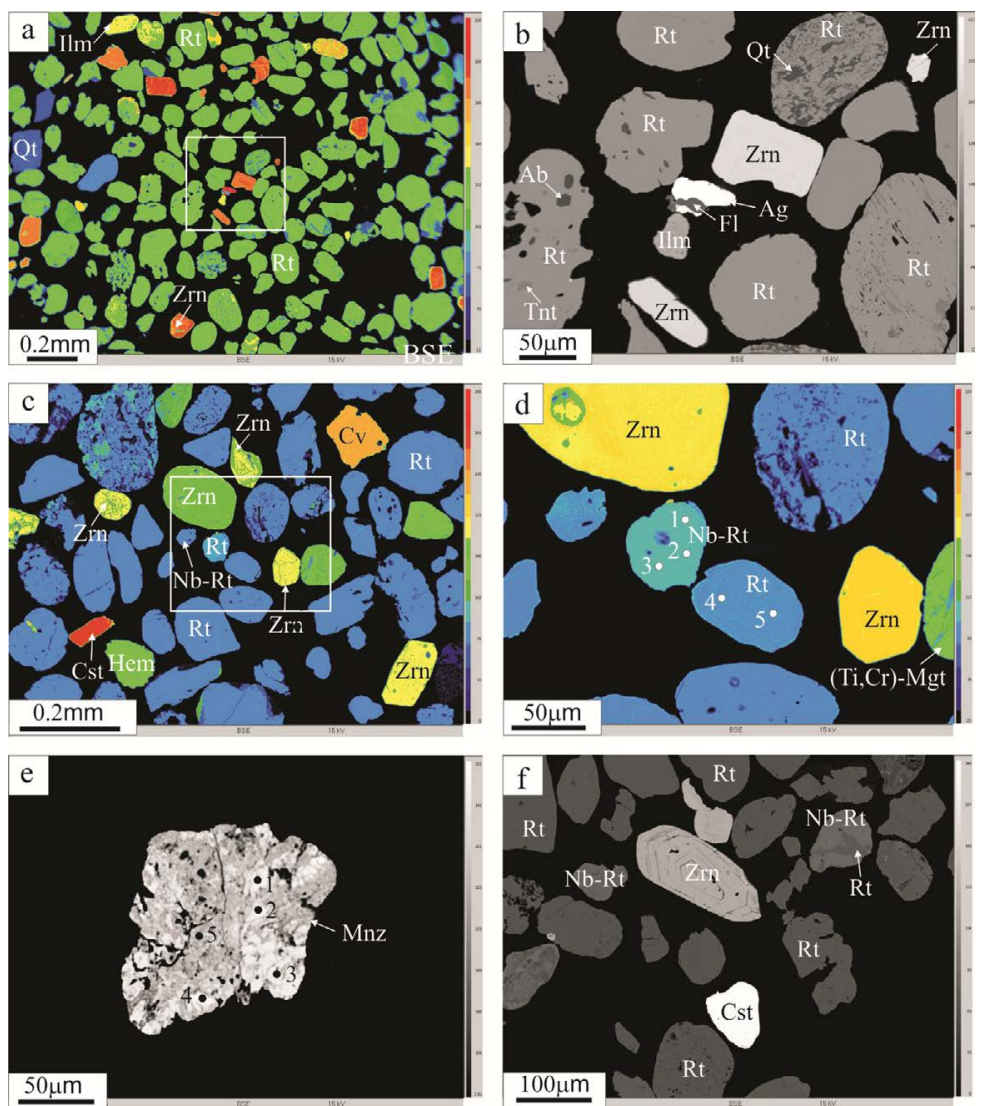

Fig. 5. The heavy minerals concentrate from the Słupsk Bank with visible well-rounded grains. Sample no. LS-K-7 a) Rutile (Rt; green) grains dominate among minerals in the heavy minerals concentrate; $\mathrm{Zrn}$ - zircon (orange); Ilm - ilmenite; Qt - quartz (blue). BSEI. Fragment in square enlarge on the next photo, b) Grains of rounded rutile, together with zircon (Zrn) and ilmenite ( $\mathrm{Ilm}$ ) and with single grain of native silver intercalated with fluorite (Fl). Ab - albite; Tnt - titanite; BSEI, c) BSEI in artificial colors reveals different minerals in heavy

minerals concentrate; $\mathrm{Nb}-\mathrm{Rt}$ - $\mathrm{Nb}$ rutile; $\mathrm{Rt}$ - rutile; $\mathrm{Zrn}$ - zircon; Hem - hematite; Cst - cassiterite; $\mathrm{CV}$ - covellite. Fragment in square enlarge on the next photo, d) BSEI in artificial colors with visible point of SEM analyses. Zrn - zircon; Rt - rutile; (Ti, Cr)-Mgt - (Ti,Cr) - magnetite. BSEI/field 03/photo-2, e) Rounded and fractured grain of monazite (Mnz) with visible point of SEM analyses. BSEI/field 04/photo-2, e) Rounded grains of rutile (Rt), zircon ( $\mathrm{Zrn}$ ) and cassiterite (Cst). In some rutile grains are visible darker parts enriched in niobium (Nb-Rt). BSEI

Rys. 5. Koncentrat minerałów ciężkich z Ławicy Słupskiej z widocznym dobrym obtoczeniem ziarn.

Próbka nr LS-K-7. a) Ziarna rutylu (Rt; zielony) dominują wśród minerałów koncentratu; Zrn - cyrkon (pomarańczowy); Ilm - ilmenit; Qt - kwarc (niebieski). BSEI. Fragment w prostokącie jest powiększony na następnym zdjęciu, b) Obtoczone ziarna rutylu wraz z cyrkonem (Zrn) i ilmenitem (Ilm) oraz z pojedynczym ziarenkiem srebra rodzimego w przeroście z fluorytem ( $\mathrm{Fl})$. Ab - albit; Tnt - tytanit; BSEI,

c) BSEI - Obraz elektronów wstecznie odbitych w sztucznych barwach uwypukla różnice w obecności minerałów w koncentracie; Nb-Rt - Nb rutyl; Rt - rutyl; Zrn - cyrkon; Hem - hematyt; Cst - kasyteryt; $\mathrm{Cv}$ - kowelin. Fragment w prostokącie jest powiększony na następnym zdjęciu, d) BSEI w sztucznych barwach z widocznymi punktami analiz SEM. Zrn - cyrkon; Rt - rutyl; (Ti, Cr)-Mgt - (Ti,Cr) - magnetyt. BSEI/obszar 03/foto-2, e) Zaokrąglone i spękane ziarno monacytu (Mnz) z widocznymi punktami analiz SEM. BSEI/obszar 04/foto-2, e) Zaokrąglone ziarna rutylu (Rt), cyrkonu (Zrn) i kasyterytu (Cst).

W niektórych ziarnach rutylu widoczne są ciemniejsze strefy wskazujące na domieszki niobu (Nb-Rt). BSEI 
Table 5. WDS composition (in wt.\%) of rutile, Nb-rutile and pirochlor grains in the heavy minerals concentrate from the Słupsk Bank (LS-K-7)

Tabela 5. Skład chemiczny (w \% wag.) rutylu, Nb-rutylu i pirochloru z koncentratu minerałów ciężkich z Ławicy Słupskiej (LS-K-7) na podstawie badań na mikrosondzie elektronowej (EPMA)

\begin{tabular}{|c|c|c|c|c|c|c|c|c|c|}
\hline \multicolumn{6}{|c|}{ LS_K-7_area-03_photo-2 } & \multicolumn{4}{|c|}{ LS_K-7_area-07_photo-2 } \\
\hline Formula & $1 / 1$ & $2 / 1$ & $3 / 1$ & $4 / 1$ & $5 / 1$ & $1 / 1$ & $2 / 1$ & $3 / 1$ & $4 / 1$ \\
\hline \multicolumn{10}{|c|}{ Weight $\%$ Oxide } \\
\hline $\mathrm{F}$ & 0 & 0 & 0 & 0.004 & 0 & 2.663 & 2.66 & 2.655 & 2.681 \\
\hline S & 0.002 & 0.021 & 0.004 & 0 & 0.002 & 0.052 & 0.053 & 0.05 & 0.06 \\
\hline $\mathrm{Cl}$ & 0.014 & 0 & 0.001 & 0.005 & 0.005 & 0 & 0 & 0.023 & 0.013 \\
\hline $\mathrm{Na}_{2} \mathrm{O}$ & 0 & 0 & 0 & 0 & 0 & 3.627 & 3.674 & 3.652 & 3.771 \\
\hline $\mathrm{K}_{2} \mathrm{O}$ & 0.01 & 0 & 0.013 & 0.007 & 0.01 & 0.013 & 0.011 & 0.012 & 0.002 \\
\hline $\mathrm{MgO}$ & 0 & 0 & 0 & 0 & 0 & 0.147 & 0.148 & 0.144 & 0.269 \\
\hline $\mathrm{CaO}$ & 0.008 & 0.005 & 0 & 0.003 & 0.011 & 17.122 & 17.121 & 17.131 & 17.109 \\
\hline $\mathrm{MnO}$ & 0.034 & 0.012 & 0 & 0 & 0 & 0.175 & 0.171 & 0.181 & 0.167 \\
\hline $\mathrm{FeO}$ & 3.29 & 3.192 & 3.352 & 0.635 & 0.647 & 2.111 & 2.056 & 1.983 & 2.008 \\
\hline $\mathrm{SrO}$ & 0 & 0.014 & 0 & 0.018 & 0.018 & 0.295 & 0.261 & 0.24 & 0.233 \\
\hline $\mathrm{PbO}$ & 0.013 & 0.009 & 0 & 0.019 & 0.004 & & & & \\
\hline $\mathrm{Al}_{2} \mathrm{O}_{3}$ & 0.018 & 0.036 & 0.038 & 0.099 & 0.077 & 0.118 & 0.119 & 0.137 & 0.147 \\
\hline $\mathrm{Y}_{2} \mathrm{O}_{3}$ & 0 & 0.004 & 0.015 & 0 & 0 & 0.294 & 0.273 & 0.264 & 0.29 \\
\hline $\mathrm{La}_{2} \mathrm{O}_{3}$ & 0.053 & 0 & 0.03 & 0 & 0 & 0.98 & 0.791 & 0.852 & 0.761 \\
\hline $\mathrm{Ce}_{2} \mathrm{O}_{3}$ & 0.201 & 0.172 & 0.179 & 0.156 & 0.196 & 4.712 & 4.797 & 4.565 & 4.467 \\
\hline $\mathrm{Pr}_{2} \mathrm{O}_{3}$ & 0 & 0.05 & 0 & 0 & 0.048 & 0.278 & 0.372 & 0.156 & 0.521 \\
\hline $\mathrm{Nd}_{2} \mathrm{O}_{3}$ & 0 & 0 & 0 & 0 & 0 & 1.003 & 1.106 & 1.079 & 1.105 \\
\hline $\mathrm{Sm}_{2} \mathrm{O}_{3}$ & 0 & 0 & 0 & 0 & 0.024 & 0.157 & 0.183 & 0.186 & 0.066 \\
\hline $\mathrm{SiO}_{2}$ & 0.025 & 0.004 & 0.013 & 0.014 & 0.041 & 0.031 & 0.017 & 0.021 & 0.022 \\
\hline $\mathrm{TiO}_{2}$ & 89.533 & 90.484 & 89.592 & 97.615 & 97.57 & 0.241 & 0.224 & 0.174 & 0.194 \\
\hline $\mathrm{ThO}_{2}$ & 0 & 0 & 0 & 0 & 0.01 & 0.039 & 0.056 & 0.045 & 0.052 \\
\hline $\mathrm{UO}_{2}$ & 0.005 & 0 & 0 & 0.001 & 0.023 & 0 & 0 & 0.005 & 0 \\
\hline $\mathrm{P}_{2} \mathrm{O}_{5}$ & 0.008 & 0.012 & 0.016 & 0 & 0 & 0.051 & 0.008 & 0 & 0.025 \\
\hline $\mathrm{Nb}_{2} \mathrm{O}_{5}$ & 5.662 & 5.418 & 5.773 & 0.917 & 0.912 & 63.224 & 63.838 & 63.638 & 63.429 \\
\hline $\mathrm{Ta}_{2} \mathrm{O}_{5}$ & 0.351 & 0.133 & 0.408 & 0.056 & 0.04 & 0 & 0.048 & 0.102 & 0.259 \\
\hline Total & 99.226 & 99.565 & 99.434 & 99.548 & 99.64 & 97.335 & 97.987 & 97.295 & 97.65 \\
\hline
\end{tabular}


Microscope and microprobe studies showed the domination of rutile in the $\mathrm{S}(\mathrm{Zr})$ heavy minerals concentrate sample. Rutiles constitute almost $65-70 \%$ of all grains (Fig. 5a). Rutiles have sizes ranging from 50 to $150 \mu \mathrm{m}$ in diameter, rounded edges and they are commonly intercalated with quartz and ilmenite or less frequently with xenotime or zircon. The rutile variety also appears with a high admixture of niobium (5-6 weight $\%$ of $\mathrm{Nb}_{2} \mathrm{O}_{5}$; Table 5). Nb-bearing rutile's are generally a bit smaller (approx. $50 \mu \mathrm{m}$ in diameter) in relation to common rutile grains (Fig. 5c-5d, 5f). Albite or titanite inclusions have been found within the larger grains of rutile (about $100 \mu \mathrm{m}$ in diameter) (Fig. 5B). The zircon grains are the second component (a dozen percent share) in the heavy minerals concentrate. Zircons generally have sizes ranging from 70 to $130 \mu \mathrm{m}$ in diameter. Single grains of copper minerals (covellite and cuprite), cassiterite (Fig. 5c, 5f) as well as native silver intercalated with fluorite appear in the concentrate (Fig. 5a, 5b). Monazite found in concentrate revealed an usually high concentration of LREO (sum $>50$ weight $\%$; Table 4) and moderate $\mathrm{ThO}_{2}$ admixtures (7-10 weight \%). On the other hand, thorium and yttrium enrichments (maximum contents of $\mathrm{ThO}_{2}$ and $\mathrm{Y}_{2} \mathrm{O}_{5} \sim 25$ and 13.4 weight \%, respectively) are poorer in LREEO (sum 30-40 weight \%) monazite.

In the heavy minerals concentrate well-rounded grains of magnetite $(80-200 \mu \mathrm{m}$ in diameter), ilmenite and single grains of xenotime (of sizes $70-110 \mu \mathrm{m}$ in diameter) are present also as well as strongly altered grains of monazite (up to $150 \mu \mathrm{m}$ in diameter; Fig. 5e; Table 4). Monazite was also found in the form of inserts in zircon grains. Xenotime has
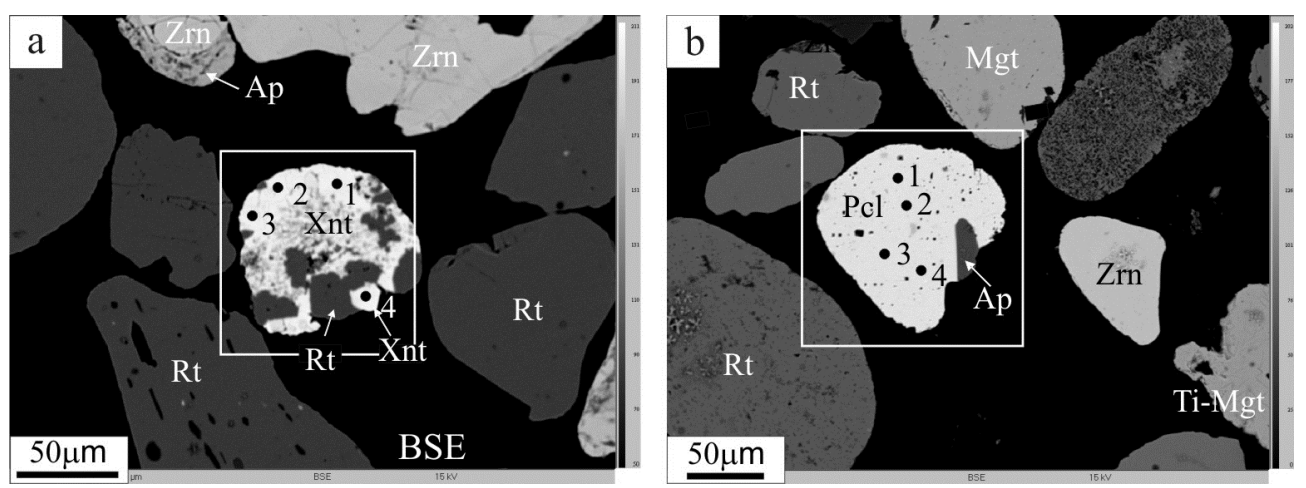

Fig. 6. The heavy minerals concentrate from the Słupsk Bank with visible well-rounded grains of different minerals. Sample no. LS-K-7

a) Well-rounded grain of xenotime (Xnt; with visible point of SEM analyses) intercalated with rutile (Rt).

The one of the zircon (Zrn) grain with apatite (Ap) rim is visible. BSEI/field 06/photo-1, b)

Grains of rounded pyrochlore (Pcl) with insert of apatite (Ap). Ti-Mgt - Ti-magnetite; BSEI/field 07/photo-2

Rys. 6. Koncentrat minerałów ciężkich z Ławicy Słupskiej

z widocznym dobrym obtoczeniem różnych minerałów. Próbka nr LS-K-7

a) Dobrze obtoczone ziarno ksenotymu (Xnt; z widocznymi punktami analiz SEM) przerastające się z rutylem

(Rt). Widoczne jest jedno z ziarn cyrkonu (Zrn) z otoczką apatytu (Ap). BSEI/obszar 06/foto-1,

b) Zaokrąglone ziarna pirochloru (Pcl) z wrostkami apatytu (Ap). Ti-Mgt - Ti-magnetyt; BSEI/obszar 07/foto-2 
a high contents of yttrium $\left(\mathrm{Y}_{2} \mathrm{O}_{3}, 38-40.5\right.$ weight \%) and HREEO (sum $>25$ weight \%; Table 3). Xenotime may form intercalation with rutile (Fig. 6A). In addition, a strongly rounded single grain of pirochlor (with a diameter of approx. $100 \mu \mathrm{m}$ ) and a high content of $\mathrm{Nb}\left(\mathrm{Nb}_{2} \mathrm{O}_{5} 63-64\right.$ weight \%; Table 5), and low admixture of $\mathrm{Ce}$ and $\mathrm{La}$ (c.a. 6-7 weight \% of LREEO) with the apatite inserts were identified (Fig. 6b).

\subsection{Hel Peninsula}

As a result of the ICP-MS chemical analysis, the presence of rare earths represented mainly by the lanthanides and another elements such as thorium, yttrium and scandium was found in one of the samples (Table 1). In the shore sands sample (\# He2) from the trench (Fig. 3B) the significant enrichment in the light lanthanides group with a high proportion of cerium, and then lanthanum and neodymium is characteristic. The concentration of yttrium is also noteworthy. Besides, part of the thorium is also high in this sample (147.4 ppm). The sum of REE in the first sample (\#Hel) from this area is very low (40 ppm). In turn, the sum of REE is much higher in the second sample -0.14 weight $\%$. In this sample, the light lanthanides also dominate. The cerium concentration reaches c.a. $0.6 \mathrm{~g} / \mathrm{kg}$, and lanthanum and neodymium concentration exists in the amount of 0.3 and $0.26 \mathrm{~g} / \mathrm{kg}$, respectively. The content of neodymium and yttrium is in the range of $100-250 \mathrm{mg} / \mathrm{kg}$. Components of the heavy lanthanides subgroups are in the range from several to twenty some $\mathrm{mg} / \mathrm{kg}$ (for example Dy). In comparison with a beach sands sample, (Hel) collected from the surface has a significantly increased concentration of REE ( $>40$-times). And if we compared this sample to the other 3 Baltic marine sand samples from the Odra Bank (Table 1), we can notice that He2 sample enrichment in REE is from 5 to 15 times greater. The exceptions are $€ \mathrm{O}(\mathrm{Zr})$ and $\mathrm{\iota S}(\mathrm{Zr})$ samples of heavy minerals concentrates which contain total sum of rare earths from 4 to 6 times higher than in the He 2 sample. The comparison of REE content in samples to chondrite (Fig. 7) points to their considerable enrichment in LREE (3 samples are enriched more than 1000 times) and much lower in HREE (at the level of about 100-times). In all the samples examined by ICP-MS, the total sum of REE ranges from traces (40 ppm) to $0.9 \%$ (Table 1 ).

The distribution of rare earth elements content in the all samples tested by ICP-MS method indicate a predominance of light lanthanides, including cerium, which remains in close correlation with the presence of grains of monazites. Monazites have been found up to a few percent of total volume of heavy minerals concentrate. The chemical composition of monazites revealed during microprobe analyses indicates a high contents of $\mathrm{Ce}_{2} \mathrm{O}_{3}$ (max. 32.5 weight \%), and of $\mathrm{Nd}_{2} \mathrm{O}_{3}\left(11-13\right.$ weight \%) and moderate contents of $\mathrm{La}_{2} \mathrm{O}_{3}$ (max. 15.5 weight \%). In turn, relatively high yttrium content in the heavy minerals concentrate is due to the presence of xenotime. Increased contents of neodymium $(0.017 \%)$ and thorium $(0.0008 \%)$ were also found in this sample. The neodymium content is strongly correlated with the presence of pirochlor and $\mathrm{Nb}$-bearing rutile in concentrate grains. On the other 


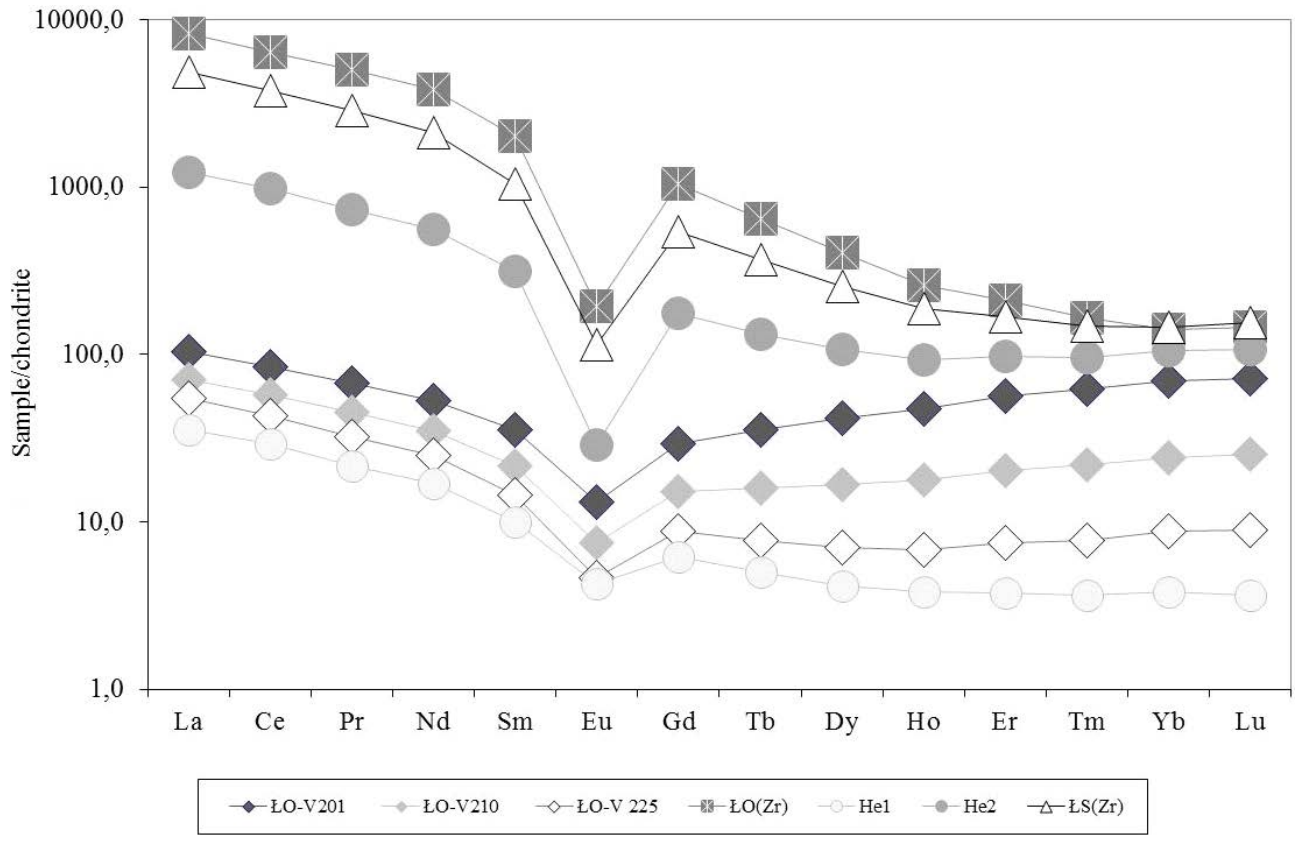

Fig. 7. The characteristics of the rare earths in the samples of marine sands and zircon concentrates [samples \# $€ \mathrm{O}(\mathrm{Zr})$ and $€ S(\mathrm{Zr})]$ from the Baltic Sea area normalized to chondrite (after McDonough and Sun 1995)

Rys. 7. Znormalizowany wykres logarytmiczny koncentracji REE w próbkach piasków i koncentratów cyrkonu [próbki nr: $€ \mathrm{O}(\mathrm{Zr})$ i $Ł S(\mathrm{Zr})$ ] z regionu Morza Bałtyckiego w stosunku do zawartości w chondrycie (wg McDonough i Sun 1995)

hand, the enrichments in thorium are strongly correlated with the appearance of Th-bearing apatite and monazite in concentrate grains.

\section{Summary}

The rare earth elements results of pilot analytical work (ICP-MS methodology) in the marine sands of the Baltic Sea presented in the article have shown that some heavy minerals concentrate samples from the Odra and Słupsk Banks as well as in the one sample from the Hel Peninsula (16.6 km stretch of beach) are reaching a concentration that may be of interest in terms of economy. The results of this investigation confirmed the dependence of the REE concentration with the percentage of heavy minerals content in the marine sands. In the examined samples, it is the vast preponderance of LREE among the rare earths. The highest concentration mainly is achieved by cerium and almost two times lower by lanthanum. The total REE content in the considered 3 richest samples is from c.a. $0.14 \%$ (He2 sample from Hel Peninsula) to $0.9 \%$ ( $\mathrm{LO} / \mathrm{Zr}$; heavy minerals (zircon) concentrate from the Odra Bank). 
Microprobe investigations indicate that monazite is the main carrier of LREE in marine sands, and a high yttrium contents is correlated with the appearance of xenotime among the heavy minerals. Moreover, pirochlor and Nb-bearing rutile are responsible for a high neodymium concentration. Thorium is considered as strongly correlated with the appearance of Th-bearing apatite and monazite in concentrate grains. The enrichments in REE concentration is accompanied by the high contents of Th (150-900 ppm).

The previous recognition of heavy mineral resources in the Baltic sands is limited to a small area on the Odra and Słupsk Banks. More research should be done in the prospective areas situated to the North-East from the already documented placer fields with estimated resources on the Odra Bank. Furthermore, new work should be carried out in the tentatively identified areas on the Słupsk Bank, as well as along the underwater slope (paleo-slope) and on the beaches of the Hel Peninsula. Research on the minerals identification of rare earths and on the technology of recovery of REE-bearing minerals from heavy minerals concentrates should be carried out in parallel with the documentary work. This source of LREE from the heavy mineral concentrates received from the Baltic sandbanks may be interesting for recovery by the domestic economy. The presence of LREE, especially cerium, in heavy minerals concentrate is valuable due to its use in the production of catalytic converters or metal alloys. In addition, lanthanum, which is used in vehicles with hybrid drive (batteries), $\mathrm{x}$-ray film or catalyst in the process of refining crude oil is present in the concentrate. In turn, neodymium is consumed during the production of strong neodymium magnets as well as for the fabrication of lasers.

This work was supported by the internal PGI-NRI research grant project no. 61.6705.1301.00.0 (Mikulski et al. 2014). The publication of this paper was financed by National Fund for Environmental Protection and Water Management, Project no. 22.9510.1601.02.1 - titled "Polish Geological Survey information activities in the area of access to data on the occurrence and availability of mineral resources that are of key importance to the national economy and energy security of Poland". I. Wysocka are acknowledge for chemical analysis.

\section{REFERENCES}

Akerman, K. and Krajewski, J. 1959. Studia nad selektywnym wzbogacaniem bałtyckich piasków cyrkononośnych. cz. II. Przem. Chem. Vol. 38 (in Polish).

Bagdach, Z. and Lasko, S. 1989. Technologia pozyskiwania ilmenitu, rutylu, cyrkonu i granatów z piasków morskich Ławicy Słupskiej i Odrzanej. Technika i gospodarka morska 7 (452), pp. 330-332 (in Polish).

Brański, P. and Mikulski, S.Z. 2016. Rare earth elements distribution in fine-grained deposits from the uppermost Triassic and Lower Jurassic of the Polish Basin: provenance and weathering of source area (preliminary results). Geological Quarterly Vol. 60(2). pp. 441-450.

Chakhmouradian, A.R. and Wall, F. 2012. Rare Earth Elements: Minerals. Mines. Magnets (and More). Elements Vol. 8 (5), pp. 333-340.

Collins, L.B. and Baxter, J.L. 1984. Heavy mineral-bearing strandline deposits associated with high-energy beach environments, southern Perth Basin, Western Australia. Australian Journal of Earth Sciences: An International Geoscience Journal of the Geological Society of Australia Vol. 31 (3), pp. 287-292. 
Dill, H.G. 2007. Grain morphology of heavy minerals from marine and continental placer deposits, with special reference to Fe-Ti oxides. Sedimentary Geology Vol. 198, pp. 1-27.

Dill et al. 2012 - Dill, H.G., Weber, B. and Klosa, D. 2012. Morphology and mineral chemistry of monazite-zircon-bearing stream sediments of continental placer deposits (SE Germany): Ore guide and provenance marker. Journal of Geochemical Exploration Vol. 112, pp. 322-346.

Economic, 1988. Economic and Social Commission for Asia and the Pacific and Australian Bureau of Mineral Resources, Geology and Geophysics, 1988, Mineral sands in Asia and the Pacific: New York, United Nations, Mineral Concentrations and Hydrocarbon Accumulations in the ESCAP Region, Vol. 4, p. 129.

EU Resolution, 2011. An effective raw materials strategy for Europe. European Parliament resolution of 13 September 2011. [Online] Available at: http://eur lex.europa.eu/LexUriServ/LexUriServ.:2013:051E:0021:0037:EN:PDF [Accessed: 9.10.2016].

Galos et al. 2012 - Galos, K., Nieć, M., Radwanek-Bąk, B., Smakowski, T. and Szamałek, K. 2012. Bezpieczeństwo surowcowe Polski w Unii Europejskiej i na Świecie. Biuletyn Pań. Inst. Geol. Vol. 452, pp. 43-52 (in Polish).

Galos, K. and Smakowski, T. 2008. Nowa polityka surowcowa Unii Europejskiej w obszarze surowców nie-energetycznych. Gospodarka Surowcami Mineralnymi - Mineral Resources Management Vol. 24(4). pp. 75-90 (in Polish)

Haas et al. 1995 - Haas, J.R., Shock, E.L. and Sassani, D.C. 1995. Rare earth elements in hydrothermal systems: Estimates of standard partial molar thermodynamic properties of aqueous complexes of the rare earth elements at high pressures and temperatures. Geochimica et Cosmochimica Acta Vol. 59, pp. 4329-4350.

Haque et al. 2014 - Haque, N., Hughes, A., Lim, S. and Vernon, C. 2014. Rare Earth Elements: overview of mining, mineralogy, uses, sustainability, and environmental impact. Resources 2014 Vol. 3, pp. 614-635.

Hatch, G.P. 2012. Dynamics in the global market for rare earths. Elements Vol. 8, pp. 341-346.

Hedrick J.B. 1997. Rare-earths. Mineral Industry Surveys. Annual review 1996. USGS Reston.

Jones, Ph. 1994. Baltic mineral sands Project. Inferred mineral resource estimate. [App. to:] Kramarska R. 1993. Poszukiwanie i rozpoznanie złóż minerałów ciężkich w rejonie Ławicy Odrzanej. Opracowanie i ocena wyników fazy 1 i 2 . NAG PIG-PIB OGM Gdańsk. Nr arch. 338.

Jurowska et al. 1978 - Jurowska, Z., Masłowska, M., Michałowska, M. and Trokowicz, D. 1978. Mapa osadów dennych Ławicy Odrzanej w skali 1200000 z uwzględnieniem koncentracji minerałów ciężkich. CAG PIG-OGM Gdańsk. Nr arch. 47 (in Polish).

Juskowiak et al. 1976 - Juskowiak, O., Gustkowicz, S. and Sokołowska, G. 1976. Badania technologiczne frakcji piaszczystej morskich osadów Bałtyku Poludniowego. NAG PIG-PIB. Warszawa. nr inw. 21172 (in Polish).

Kanasiewicz J. 1987. Pierwiastki ziem rzadkich. Dolny Śląsk [W:] Budowa geologiczna Polski. Złoża surowców mineralnych. T. VI (red. R. Osika), pp. 369-371. Warszawa: Wyd. Geol.

Kaulbarsz et al. 2013 - Kaulbarsz, D., Jurys, L., Kramarska, R. and Przezdziecki, P. 2013. Dokumentacja geologiczna złoża piasków z minerałami ciężkimi Ławica Odrzana pola A i B w kat. D. NAG PIG-PIB. OGM Gdańsk, nr arch. 1110 (in Polish).

Klupa, A. 2012. Cenniejsze niż złoto? Metale ziem rzadkich w światowej strategii gospodarczej. Przegląd Strategiczny 1, pp. 239-251 (in Polish).

Kotliński, R. 1985. Osady dna Lawicy Słupskiej. Biuletyn Instytutu Geologicznego Vol. 352, pp. 5-56 (in Polish).

Kotliński, R. and Kramarska, R. 1977. Badania nad wytypowaniem najbardziej perspektywicznego rejonu dla poszukiwań złóż rozsypiskowych minerałów ciężkich $w$ strefie szelfu poludniowego Bałtyku. NAG PIG. OGM Gdańsk. Nr arch. 49 (in Polish).

Kramarska, R. 1991. Badania mineralogiczne i analiza porównawcza składników użytecznych wybranych rejonów Ławicy Odrzanej. NAG PIG OGM Gdańsk, Nr arch. 225 (in Polish).

Kramarska, R. 1993. Poszukiwanie i rozpoznanie złóż minerałów ciężkich w rejonie Ławicy Odrzanej. Opracowanie i ocena wyników fazy 1 i 2. NAG PIG-PIB Oddział Geologii Morza w Gdańsku. Nr arch. 338 (in Polish).

Kramarska, R. 1998. Origin and development of the Odra Bank in the light of the geologic structure and radiocarbon dating. Geological Quarterly Vol. 42 (3), pp. 277-288.

Kramarska et al. 2005 - Kramarska, R., Jegliński, W., Jurys, L., Przezdziecki, P., Uścinowicz, Sz. and Zachowicz, J. 2005. Atlas parametrów litologicznych osadów powierzchniowych poludniowego Bałtyku ze szczególnym uwzględnieniem geologiczno-górniczych warunków występowania surowców okruchowych. NAG PIG-PIB. OGM Gdańsk. Nr arch. 753 (in Polish). 
Kramarska et al. 2016 - Kramarska R., Jegliński W., Kaulbarsz D., Pączek U., Przezdziecki P., Bojakowska I., Koszka-Maroń D., Relisko-Rybak J., Uścinowicz Sz. 2016. Czwartorzęd Zatoki Pomorskiej i perspektywy surowcowe. Przeglad Geologiczny Vol. 64(8), pp. 552-563 (in Polish).

Krzemińska, E. and Krzemiński, L. 2012. Alkaliczna intruzja syenitowa Mławy a perspektywy występowania pierwiastków ziem rzadkich. Biuletyn Państwowego Instytutu Geologicznego Vol. 448, pp. 401-08 (in Polish).

Kubicki, S. 1987. Pierwiastki ziem rzadkich. [W:] Budowa geologiczna Polski. Złoża surowców mineralnych. Tom VI (red. R. Osika), pp. 371-372. Warszawa: Wyd. Geologiczne (in Polish).

Kynicky et al. 2012 - Kynicky, J., Smith, M.P. and Xu, C. 2012. Diversity of Rare Earth Deposits: The Key Example of China. Elements Vol. 8, pp. 361-367.

Leontjew et al. 1982 - Leontjew, O.K., Nikiforow, L.G., Sajanow, G.A. 1982. Geomorfologia brzegów morskich. Warszawa: Wyd. Geologiczne (in Polish).

Long et al. 2010 - Long K.R., Van Gosen, B.S., Foley, N.K. and Cordier D. 2010. The Principal Rare Earth Elements Deposits of the United States - A Summary of Domestic Deposits and a Global Perspective. US Geological Survey Scientific Investigations Report 2010-5220.

Łoziński, J. and Masicka, H. 1959. Badania minerałów ciężkich w piaskach plażowych Zatoki Gdańskiej. Rocznik Pol. Tow. Geol. Vol. 32, pp. 579-599 (in Polish).

Łuszczkiewicz. A. 1984. Technologiczna ocena możliwości wzbogacania piasków morskich Bałtyku. Pr. Nauk. Inst. Chemii Nieorg. i Metalurgii Pierw. Rzadkich Polit. Wroct., Vol. 51. Seria: Konferencje Vol. 10, pp. 107-116 (in Polish).

Łuszczkiewicz et al. 1988 - Łuszczkiewicz, A., Kurzyca, M., Steinhoff, J. and Świerkot-Kopała, A. 1988. Ocena możliwości pozyskiwania minerałów ciężkich z piasków Ławic Słupskiej i Odrzanej. Przegląd Górniczy Vol. 10, pp. 12-17 (in Polish).

Mączka, L. and Racinowski, R. 1960. Formy występowania skupień minerałów ciężkich na plażach Pomorza Zachodniego. Kwartalnik Geologiczny Vol. 13, pp. 221-232 (in Polish).

Mapa Geologiczna dna Bałtyku w skali 1:200 000. 1989-1995. (red. J.E. Mojski). WarszawaŁ Państw. Inst. Geol.

Mariano, A.N. and Mariano, A. 2012. Rare earth mining and exploration in North America. Elements Vol. 8, pp. $369-376$

McDonough, W.F. and Sun, S.S. 1995. Composition of the Earth. Chemical Geology Vol. 120, pp. 223-253.

Mikulski et al. 2014 - Mikulski, S.Z., Oszczepalski, S., Brański, P., Kozdrój, W., Markowiak, M., Kramarska, R., Chmielewski, A., Sadłowska, K. and Damrat, M. 2014. Weryfikacja stanu wiedzy o mineralizacji metalami ziem rzadkich (REE) wraz z pilotażowa ocena ich perspektyw złożowych $w$ Polsce z wyłaczeniem obszaru kratonu wschodnioeuropejskiego. 1463/2016 NAG Warszawa (in Polish).

Mikulski et al. 2015 - Mikulski, S.Z., Markowiak, M., Sadłowska, K., Chmielewski, A., Zieliński, G. 2015. Pilotażowe badania pierwiastków ziem rzadkich w strefie kontaktu bloku małopolskiego z blokiem górnośląskim. Biuletyn Państwowego Instytutu Geologicznego Vol. 465, pp. 77-98 (in Polish).

Moss et al. 2011 - Moss. R.L., Tzimas, E., Kara, H., Willis, P. and Kooroshy J. 2011. Critical Metals in Strategic Energy Technologies Appendices, Assesing Rare Metals as supply-chain bottlenecks in Low-Carbon Energy Technologies: JRC European Commission, pp. 1-159.

Opinion 2006. Opinion of the European Economic and Social Committee on Risks and problems associated with the supply of raw materials to European industry. Official Journal 2006/C 309/16.

Oszczepalski et al. 2016 - Oszczepalski, S., Chmielewski, A. and Mikulski, S.Z. 2016. Controls on the distribution of rare earth elements in the Kupferschiefer series of SW Poland. Geological Quarterly Vol. 60 (4). DOI: http://dx.doi.org/10.7306/gq.1325.

Paulo, A. 1993. Dlaczego nie należy poszukiwać złóż rud niobu i pierwiastków ziem rzadkich w Polsce? Pol. Tow. Mineral. Pr. Specjal. Vol. 3, pp. 55-77 (in Polish).

Paulo, A. 1999. Pierwiastki ziem rzadkich pod koniec XX wieku. Przeglad Geologiczny Vol. 47(1), pp. 34-41 (in Polish).

Paulo, A. and Krzak, M. 2015. Pierwiastki ziem rzadkich. Metale rzadkie. Kraków: Wyd. AGH (in Polish).

Radwanek-Bąk, B. 2011. Zasoby kopalin Polski w aspekcie oceny surowców krytycznych Unii Europejskiej. Gospodarka Surowcami Mineralnymi - Mineral Resources Management Vol. 27, pp. 5-19 (in Polish).

Rosińska, M. 1981. Badania technologiczne złóż rozsypiskowych różnych surowców w akwenie Battyku (próby odzysku cyrkonu i ziem rzadkich). NAG PIG-PIB Warszawa (in Polish). 
Sawicka, E. 1953. Minerały ciężkie w piaskach plażowych polskiego wybrzeża Bałtyku. Biuletyn Instytutu Geologicznego, pp. 29-35 (in Polish).

Smakowski, T. 2011. Surowce mineralne - krytyczne czy deficytowe dla gospodarki UE i Polski. Zeszyty Naukowe Instytutu Gospodarki Surowcvami Mineralnymi i Energia PAN Vol. 81, pp. 59-68 (in Polish).

Smakowski et al. 2012 - Smakowski, T., Ney, R. and Galos, K., red. Minerals Yearbook of Poland 2012. Mineral and Energy Economy Research Institute of the Polish Academy of Sciences 2013, 559 pp.

Szamałek, K. 2011. Rational mineral deposit management in the light of mineral resources theory. Gospodarka Surowcami Mineralnymi - Mineral Resources Management Vol. 27, pp. 5-15.

Szamałek et al. 2013 - Szamałek, K., Konopka, G., Zglinicki, K. and Marciniak-Maliszewska, B. 2013. New potential source of rare earth elements. Gospodarka Surowcami Mineralnymi-Mineral Resources Management Vol. 29(3), pp. 59-76.

[Online] Available at: http://minerals.usgs.gov/minerals/pubs/commodity/rare earths/mcs-2016-raree.pdf [Accessed: 3.9 .2016$]$

Wajda, W. 1970. Minerały ciężkie piasków dennych polskiego wybrzeża Bałtyku. Rocznik Polskiego Towarzystwa Geologicznego Vol. 40 (1), pp. 131-149 (in Polish).

Wajda, W. 1977. Badania litologiczne i mineralogiczne osadów dennych rejonu Ławicy Odrzanej. Stud. $i$ Mater. Ocean Vol. 19, pp. 265-270 (in Polish).

Wajda, W. 1980. Osady piaszczyste południowego Bałtyku w aspekcie badań przydatnych gospodarczo koncentracji minerałów ciężkich. Peribalticum I. GTN, Gdańsk, pp. 59-78 (in Polish).

Wajda, W. 1982. Banka Odry po rezultatam nowych geołogiczeskich issledowanij. Peribalticum II. GTN, Gdańsk. pp. 171-183 (in Polish).

Zwierzycki, J. 1947. Złoża cyrkonu na Pomorzu Zachodnim. Hutnik (in Polish).

\title{
PILOTAŻOWE BADANIA PIERWIASTKÓW ZIEM RZADKICH W PIASKACH MORSKICH BALTYKU WZBOGACONYCH W MINERALY CIĘŻKIE
}

\author{
Słowa kluczowe \\ pierwiastki ziem rzadkich, minerały ciężkie, piaski morskie, \\ paleo-mierzeje, Morze Bałtyckie
}

\section{Streszczenie}

Przeprowadzono pilotażowe prace nad koncentracją REE w piaskach bałtyckich za pomocą metodyki ICP-MS oraz mikrosondy elektronicznej (CAMECA SX-100). Analizy chemiczne składu jakościowego i ilościowego pierwiastków ziem rzadkich w próbkach piasków z koncentratów minerałów ciężkich z Ławicy Odrzanej oraz z Ławicy Słupskiej jak również z wkopu na plaży na Półwyspie Helskim (16,6 km plaży wybrzeża) osiągają zawartości REE, które mogą być interesujące pod względem surowcowym. Wyniki oznaczeń potwierdzają zależność koncentracji REE od procentowej zawartości minerałów ciężkich w osadach piasków morskich. Wskazują ponadto na monacyt jako główny wśród minerałów nośnik REE. W zbadanych próbkach koncentratów minerałów ciężkich oraz w próbce z Półwyspu Helskiego jest zdecydowana przewaga LREE. Najwyższe koncentracje osiąga głównie cer, a prawie dwukrotnie niższe lantan. Suma REE w wyżej wymienionych najciekawszych pod względem zawartości REE próbkach mieści się w zakresie od około 0,14\% (wkop na plaży) do 
około $0,9 \%$ (koncentrat z Ławicy Odrzanej). Wysokiej koncentracji REE towarzyszy wysoka zawartość Th (900-150 ppm). W próbkach koncentratu minerałów ciężkich pojawia się również neodym $(0,1-0,17 \% \mathrm{Nd})$, którego obecność jest związana z pojawianiem się pirochloru oraz Nb-rutylu.

Konieczne jest systematyczne rozpoznanie zasobów minerałów ciężkich w piaskach bałtyckich. Dokładniejszymi badaniami powinny być objęte obszary perspektywiczne położone na północny wschód od pól złożowych objętych dokumentacją zasobową „Ławica Odrzana”, wstępnie rozpoznane obszary na Ławicy Słupskiej oraz podwodny skłon (paleo-mierzeja) Półwyspu Helskiego.

\title{
RARE EARTH ELEMENTS PILOT STUDIES OF THE BALTIC SEA SANDS ENRICHED IN HEAVY MINERALS
}

\author{
Keywords
}

rare earth elements, heavy minerals, marine sands, paleo-shoals, Baltic Sea

\section{Abstract}

The carried out pilot work on the concentration of rare earth elements (REE) in the Baltic marine sands from the Odra and Słupsk Banks showed that in some places their accumulations are quite interesting in terms of the placer deposits and may be the subject of an interesting prospecting project. The results of ICP-MS and electron microprobe (CAMECA SX-100) investigation confirm the close relationship of REE concentration to heavy minerals content in the sediments of marine sands. It is indicated, in addition to monazite, as a primary mineral carrier of rare earth elements. The vast preponderance of light REE is noted in the samples of heavy mineral concentrates from the Odra and Słupsk Banks as well as in the beach sand sample from the Hel Peninsula. The highest concentrations are achieved mainly by cerium and almost two times less by lanthanum. The total REE in the most interesting considered samples range from c.a. $0.14 \%$ (trench on the beach) to $0.9 \%$ (heavy minerals concentrate from the Odra Bank). The high contents of REE are accompanied by a high concentration of Th $(900-150 \mathrm{ppm})$. Neodymium $(0.1-0.17 \% \mathrm{Nd})$, whose presence is associated with the presence of pyrochlore and $\mathrm{Nb}$-rutile also appears in the heavy minerals concentrate samples. It is necessary to systematically identify heavy minerals resources in the Baltic sands. More detailed research should cover the prospective areas situated to the North-East from the documented placer fields of the Odra Bank, as well as tentatively identified areas of the Słupsk Bank and submarine paleo-slope of the Hel Peninsula. 
